\title{
Parkinson's disease mouse models in translational research
}

\author{
Paul M. A. Antony $\cdot$ Nico J. Diederich • \\ Rudi Balling
}

Received: 24 February 2011/Accepted: 14 April 2011/Published online: 11 May 2011

(C) The Author(s) 2011. This article is published with open access at Springerlink.com

\begin{abstract}
Animal models with high predictive power are a prerequisite for translational research. The closer the similarity of a model to Parkinson's disease (PD), the higher is the predictive value for clinical trials. An ideal PD model should present behavioral signs and pathology that resemble the human disease. The increasing understanding of PD stratification and etiology, however, complicates the choice of adequate animal models for preclinical studies. An ultimate mouse model, relevant to address all PD-related questions, is yet to be developed. However, many of the existing models are useful in answering specific questions. An appropriate model should be chosen after considering both the context of the research and the model properties. This review addresses the validity, strengths, and limitations of current PD mouse models for translational research.
\end{abstract}

\section{Introduction}

Age-related neurodegenerative diseases are an increasing burden to an aging population. Parkinson's disease (PD), the most common neurodegenerative movement disorder, frequently occurs in an idiopathic form without clearly defined cause. Familial forms of PD, arising from monogenetic mutations, account for a minority of PD cases. The

P. M. A. Antony $(\bowtie) \cdot$ N. J. Diederich $\cdot$ R. Balling Luxembourg Centre for Systems Biomedicine (LCSB), University of Luxembourg, 162, a Avenue de la Faïencerie, 1511 Luxembourg, Luxembourg

e-mail: paul.antony@uni.lu

N. J. Diederich

Department of Neuroscience, Centre Hospitalier de Luxembourg, 4, rue Ernest Barblé, 1210 Luxembourg, Luxembourg clinical course of both idiopathic and familial forms of PD is believed to be influenced by environmental and genetic risk factors. Mouse models are powerful tools in PD translational research. However, an appropriate model should be chosen after considering both the model characteristics and the research context.

\section{The Parkinson's disease puzzle}

PD is a progressive neurodegenerative disorder clinically characterized by the cardinal symptoms of resting tremor, bradykinesia, cogwheel rigidity, and postural instability (Jankovic 2008). Responsiveness to L-3,4-dihydroxyphenylalanine (L-DOPA) and brain imaging distinguish PD from other disorders (D'Costa et al. 1995; Isaias and Antonini 2010). The pathological hallmarks of PD are loss of dopaminergic cells in the substantia nigra pars compacta and subsequent loss of dopamine innervation in the striatum (Forno 1996). Motor symptoms are the most obvious consequence of this nigrostriatal neurodegeneration. However, not only the basal ganglia but also other parts of the central nervous system as well as the autonomic nervous system are affected. A wide range of resulting nonmotor symptoms can affect the patient's quality of life (Langston 2006; Lees 2009). It has been assumed that at least some subforms of PD start not with motor but nonmotor symptoms such as hyposmia, rapid eye movement sleep behavior disorder (RBD), constipation, depression, reduced cardiac $\left[{ }^{123}\right.$ I] metaiodobenzylguanidine (MIBG) uptake, and, possibly, reduced color discrimination (Chaudhuri et al. 2006; Fujishiro et al. 2008; Hawkes 2008; Katzenschlager and Lees 2004). There is also a broad consensus that neurodegenerative processes in PD start many years before the actual onset of clinical 
manifestations (Savica et al. 2010; Tolosa et al. 2009). The not yet fully understood sequential plan underlying PD pathogenesis seems to correlate with clinical and pathological features (Hawkes et al. 2010). Lewy bodies, the histological hallmarks of $\mathrm{PD}$, are $\alpha$-synuclein-positive intracellular inclusions that are already present during the prodromal phase (Fearnley and Lees 1991). A yet asymptomatic, incidental Lewy body disease has been proposed (Markesbery et al. 2009). However, it is not yet fully understood if Lewy bodies have more protective or more destructive effects. Motor symptoms start only in the late phase of nigrostriatal degeneration, when $50-80 \%$ of nigral dopaminergic neurons are already lost (Bezard et al. 2001; Braak et al. 2003; Greffard et al. 2006). At this stage, nonmotor features remain frequent and clinically significant because they largely contribute to impaired quality of life and shortened life expectancy. Neuroprotective treatments are not yet available but are one of the priorities in current PD research. However, reliable biomarkers for early diagnosis and disease state identification are not yet available (Gasser 2009a; Schapira et al. 2009).

Consequently, at present, the diagnosis of PD is based on the above-mentioned characteristic clinical motor features. Importantly, the currently recognized monogenic familial forms of PD do not demonstrate the same clinical features as those of sporadic late-onset forms of PD. Genetic forms can present more pronounced psychiatric features and lack nonmotor symptoms. Nevertheless, the phenotypical overlapping between familial and idiopathic PD is sufficient to dissect the commonly involved pathways. These include mitochondrial dysfunction, oxidative stress, protein misfolding, protein degradation, protein aggregation, and inflammation (Schapira and Tolosa 2010). Evidently, a better understanding of the molecular basis of PD will open new routes to diagnosis and therapy (Pienaar et al. 2008; Robinson 2010). On the other hand, it will influence the choice of adequate models for translational research.

\section{Animal models for translational research in PD}

Progress in understanding the etiology of PD has provided candidate targets for neuroprotective and neurorescue interventions. However, until now, no potential protective treatment has received regulatory approval (Rascol 2009). One reason for this is the lack of good PD animal models for preclinical translational research. Animal models should fulfill specific requirements for the testing of neuroprotective therapies for PD. First, the model should induce reproducible nigral lesions. Second, the loss of dopaminergic neurons should be stable, without spontaneous recovery. Third, the model should provide a time window for the application of potential neuroprotective therapies (Emborg 2004). Ideally, a successful neuroprotective agent should prevent further behavioral changes, progressive biochemical deficits, and neurodegeneration. Thus, neuroprotection requires intervention when there are still cells left to be protected. Later interventions should be regarded as restorative strategies.

\section{Current status and remaining challenges}

Arvid Carlsson's research led to the development of L-DOPA-based treatments (Andersen 2009). Today, L-DOPA remains the gold standard treatment for PD. However, the drug has a wide range of adverse effects, most notably motor fluctuations and dyskinesias. Pharmacological strategies that avoid pulsatile dopaminergic stimulation have a substantial ameliorative effect on these syndromes. Despite these advances, disease progression remains unaffected (Lang and Obeso 2004). Finally, deep brain stimulation is the most recent symptomatic treatment that continuously and substantially reduces parkinsonian motor symptoms, whereas gait deterioration and nonmotor features continue to progress (Hamani et al. 2010).

Despite these therapeutic advances, PD patients continue to suffer from a severe reduction in quality of life. The development of interventions to stop or slow disease progression is therefore a major goal (Schapira and Tolosa 2010). The progress of this endeavor requires a better understanding of disease etiology and subtype stratification (Rajput et al. 2009). Importantly, early diagnosis enables the initiation of neuroprotective or other therapeutic interventions at less advanced stages of the disease.

\section{Current mouse models for PD}

PD mouse models are expected to closely match human pathology. The most important signs to replicate are motor symptoms, Lewy body formation, neuronal cell loss in the basal ganglia, age-related disease progression, and nonmotor symptoms. None of the current models satisfies all of these criteria. However, many models fulfill a subset. Empirical choices of adequate models to answer specific questions in translational research need to consider, case by case, the model-specific advantages and limitations.

\section{Pharmacological and neurotoxic PD models}

Reserpine

One of the earliest developed PD models was the pharmacological reserpine model, which prevents the storage of 
dopamine in presynaptic terminals, resulting in dopamine depletion in the striatum (Carlsson et al. 1957; Steg 1964). Reserpine rabbit models helped to elucidate the critical role of dopamine in the pathogenesis of PD. This finding led to the discovery of dopaminergic drugs such as L-DOPA. Despite this groundbreaking success, the reserpine model has significant limitations. Reserpine does not exclusively deplete dopamine and norepinephrine but all monoamines in a transient fashion. Another limitation of this model is that transient depletion does not mirror the progressive dopamine depletion in PD. In addition, the reserpine model does not reflect the histopathology of PD.

\section{6-Hydroxydopamine (6-OHDA)}

A few years after publication of the reserpine model, in the 1960s, nigrostriatal pathology was recognized as a primary factor for PD. In this context, the first neurotoxic models, aiming to reproduce nigrostriatal pathology, were established (Table 1). One neurotoxin found to induce PD was the dopamine analog 6-OHDA (Ungerstedt et al. 1974). 6-OHDA can be taken up into dopaminergic terminals via dopamine transporters. Inside the cell, it is metabolized, resulting in the production of hydrogen peroxide and free radicals, which induce neuronal death via mitochondrial dysfunction. 6-OHDA cannot cross the blood-brain barrier and therefore needs to be directly delivered to the brain. Ungerstedt et al. (1968) studied unilateral 6-OHDA lesions of the nigrostriatal pathway. By varying the position and extent of the lesion, different stages of human PD could be modeled. However, the 6-OHDA model has considerable limitations as well. It is a dopamine transporter-specific model and does not affect any other neurotransmitter.
Therefore, it does not replicate the full spectrum of clinical signs of human PD, i.e., the degeneration of the locus coeruleus with local depletion of norepinephrine is not replicated. In addition, the 6-OHDA-induced acute and local degeneration does not mirror the slow and extensive progression of neurodegeneration of the human disease. Finally, although lesioned animals show some of the cellular and behavioral deficits seen with the human disease, 6-OHDA-treated animals fail to develop Lewy bodies or $\alpha$-synuclein-positive inclusions.

\section{1-Methyl-4-phenyl-1,2,3,6-tetrahydropyridine (MPTP)}

In another model involving selective targeting of dopaminergic neurons in the brain, PD features are induced after administration of MPTP. The validity of the MPTP model is supported by the fact that MPTP exposure is a known, albeit rare, cause of drug-induced parkinsonism in humans (Davis et al. 1979; Langston et al. 1983). In mice, MPTP is typically administered systemically. MPTP is taken up primarily by astrocytes and converted to its metabolite MPP + . Then, it is taken up by dopaminergic neurons, where it exerts toxic effects. Interestingly, loss of dopaminergic neurons is observed not only in the basal ganglia but also in the enteric nervous system (Anderson et al. 2007). Varying regimens of MPTP delivery can produce varying degrees of nigrostriatal dysfunction. Acute dosing can produce lesions that result in mild to moderate cell loss, mimicking cell loss in early stages of human PD. Chronic dosing, consisting of long series of low-dose injections, results in more robust lesions representative of later stages of PD (Bezard et al. 1997). The MPTP mouse model has been invaluable in understanding the

Table 1 Pharmacological and toxicological models for Parkinson's disease

\begin{tabular}{|c|c|c|c|c|c|c|c|c|c|c|c|}
\hline Molecule & Administration & Level of relevance & Target & I & MS & NMS & $\mathrm{TH}$ & BG & SP & Age & Ref \\
\hline $\begin{array}{l}\text { 6-hydroxydopamine } \\
\text { (6-OHDA) }\end{array}$ & Local & $\begin{array}{r}\text { Derivate of } \\
\text { dopamine }\end{array}$ & $\begin{array}{l}\text { Causes oxidative stress after uptake } \\
\text { by dopamine transporters }\end{array}$ & $\mathrm{N}$ & $\mathrm{Y}$ & NR & $\mathrm{Y}$ & $\mathrm{Y}$ & $\mathrm{N}$ & $\mathrm{N}$ & 1 \\
\hline $\begin{array}{l}\text { 1-methyl-4-phenyl- } \\
\text { 1,2,3,4- } \\
\text { terahydropyridine } \\
\text { (MPTP) }\end{array}$ & Systemic & $\begin{array}{l}\text { Known, albeit rare, } \\
\text { cause of drug- } \\
\text { induced } \\
\text { parkinsonism in } \\
\text { humans }\end{array}$ & $\begin{array}{l}\text { Taken up by astrocytes primarily, } \\
\text { converted to MPP+, which can be } \\
\text { taken up by dopaminergic neurons, } \\
\text { where it exerts toxic effects }\end{array}$ & $\mathrm{Y}$ & $\mathrm{Y}$ & $\mathrm{Y}$ & $\mathrm{Y}$ & $\mathrm{Y}$ & DD & Y & 2 \\
\hline Rotenone & Systemic & Organic pesticide & $\begin{array}{l}\text { Elicits mitochondrial dysfunction in a } \\
\text { dopamine transporter independent } \\
\text { fashion }\end{array}$ & Y & $\mathrm{Y}$ & NR & $\mathrm{Y}$ & Y & DD & NR & 3 \\
\hline $\begin{array}{l}\text { Paraquat, combined } \\
\text { with maneb }\end{array}$ & Systemic & $\begin{array}{l}\text { Paraquat is a } \\
\text { pesticide, maneb } \\
\text { is a fungicide }\end{array}$ & $\begin{array}{l}\text { Causes redox cycling and thereby } \\
\text { oxidative stress }\end{array}$ & $\mathrm{Y}$ & $\mathrm{Y}$ & NR & $\mathrm{Y}$ & $\mathrm{Y}$ & DD & NR & 4 \\
\hline
\end{tabular}

Age = age-related progression; $\mathrm{BG}=$ neurodegeneration in the basal ganglia; $\mathrm{DD}=$ dose-dependent; $\mathrm{I}=\alpha$-synuclein positive inclusions; $\mathrm{MS}=$ motor signs; $\mathrm{N}=$ no; NMS = nonmotor signs; $\mathrm{NR}=$ not reported; $\mathrm{SP}=$ slow progression; $\mathrm{TH}=$ reduced level of tyrosine hydroxylase; $\mathrm{Y}=$ yes

References (Ref): 1 = Ungerstedt et al. 1974; 2 = Anderson et al. 2007; Bezard et al. 1997; Davis et al. 1979; Irwin et al. 1992; Langston et al. 1983; 3 = Betarbet et al. 2000; p. 4 = Manning-Bog et al. 2002; Thiruchelvam et al. 2000 
mechanisms underlying MPTP toxicity. However, despite robust replication of motor dysfunction and considerable preclinical successes in the screening for potentially therapeutic drugs, including coenzyme Q10, isradipine CR, and simvastatin (Beal et al. 1998; Ghosh et al. 2009; Meredith et al. 2008), the MPTP model has its limitations. For instance, mice may recover spontaneously after MPTP lesioning, thus hindering the assessment of therapeutic efficacy. The variability of MPTP sensitivity between distinct mouse strains and species is also problematic (Giovanni et al. 1994a, b; Sedelis et al. 2003). Studies on primates have demonstrated clear-cut parkinsonian features as well as protein aggregation after MPTP exposure. Consequently, this primate MPTP model has served as an adequate model for translational research toward the development and optimization of deep-brain stimulation therapies. In contrast, the MPTP model is less valid with other species, although as alluded above, the application of simvastatin in the MPTP mouse model produced interesting results in terms of protection against exotoxins (Ghosh et al. 2009).

\section{Rotenone}

The success of MPTP in replicating the neuropathology of human PD has led to the examination of other potential neurotoxin models for PD. Two promising models to emerge are the rotenone model and the combined paraquat/ maneb model. Rotenone is an organic pesticide that inhibits complex I of the electron transport chain. It causes mitochondrial dysfunction and ultimately leads to cell loss in the nigrostriatal pathway (Betarbet et al. 2000). Rotenone can be delivered systemically via intranigral infusion or via gastric gavage to replicate human disease initiation in enteric neurons, as proposed by Braak (Braak et al. 2003). Rotenone exerts its effects in a dopamine transporter-independent fashion, thereby eliciting mitochondrial dysfunction in nondopaminergic systems as well. Nevertheless, its neurotoxic effects are predominantly dopamine neuron-selective. Data from cell culture experiments suggest that rotenone triggers intracellular dopamine release, which could in turn explain the toxic effect on dopaminergic neurons (Inden et al. 2011). However, the variability of sensitivity between individuals and species and the potential of this toxin to induce widespread systemic toxicity (Ravenstijn et al. 2008) complicates the use of the rotenone model for translational research.

\section{Paraquat/maneb}

Paraquat is a pesticide that is first converted to a cation before being reoxidized. This reaction produces superoxide radicals, which in turn cause further redox cycling and oxidative stress. Paraquat is frequently administered in combination with maneb, a fungicide that has been linked to the development of parkinsonian symptoms in humans (Thiruchelvam et al. 2000). Exposure of rodents to a combination of paraquat and maneb results in significant nigral cell loss and nigral $\alpha$-synuclein-positive inclusions. Rats prenatally exposed to maneb show increased sensitivity to paraquat toxicity in adulthood. These observations support the multihit hypothesis of PD, which suggests that early insults can sensitize the nigrostriatal system to subsequent hits in adulthood (Thiruchelvam et al. 2000).

\section{Trichloroethylene}

Trichloroethylene (TCE), a solvent widely used as a degreasing agent, is also considered an environmental risk factor for PD (Gash et al. 2008; Goldman 2010). Peritoneal administration of TCE causes dopaminergic neuronal cell death in mice (Guehl et al. 1999). In rats, oral administration of TCE induces key features of PD, i.e., loss of nigral dopaminergic neurons, reduced mitochondrial complex I activity, oxidative stress, microglial activation, and $\alpha$-synuclein accumulation (Liu et al 2010a, b). However, the relevance of this model for translational research remains to be evaluated.

Overall, pharmacological and neurotoxic models help to understand the consequences of striatal dopamine loss and to develop current dopaminergic therapies (Bove et al. 2005). A major limitation of toxin-induced models, however, is that they do not reproduce the complete spectrum of human pathology. Although they are excellent for evaluating the role of the nigrostriatal system in PD and may be adequate for testing restorative therapeutic compounds, most of these models are limited in their ability to replicate important aspects of human PD such as its progressive nature and Lewy body formation.

\section{Genetic models for PD}

In the last decade, considerable advances have been made in the identification of genes responsible for monogenic familial PD. Since 1998, 14 different genes have been identified to cause familial PD (Schapira 2006; Schapira and Tolosa 2010). In addition, recent genome-wide association studies (GWAS) led to the identification of yet another set of risk-associated genes. Besides its role in familial PD, $\alpha$-synuclein is, worldwide, the most common risk factor for idiopathic PD (Pankratz et al. 2009; Satake et al. 2009). Strong association signals were also identified at the MAPT and LRRK2 loci (Simon-Sanchez et al. 2009). Other important risk factors for PD are mutations in the glucocerebrosidase gene (Sidransky et al. 2009). A more 
recently identified risk factor for PD, named PARK16, is associated with reduced risk for PD (Tan et al. 2010). Most recently, five additional PD risk factors have been reported: ACMSD, STK39, MCCC1/LAMP3, SYT11, and CCDC62/HIP1R (International Parkinson Disease Genomic Consortium 2011). As PD appears to be a complex genetic disease sensitive to environmental factors, the discovery of genetic factors in PD led to a new generation of PD models: the genetic PD mouse models.

\section{$\alpha$-Synuclein models}

The very first identified mutations leading to familial PD were located in the gene encoding $\alpha$-synuclein (ChartierHarlin et al. 2004; Ibanez et al. 2004; Kruger et al. 1998; Polymeropoulos et al. 1997). In addition to single nucleotide polymorphisms (SNPs), rare triplications and duplications of the $\alpha$-synuclein gene (SNCA) were reported in human PD (Ahn et al. 2008; Gasser 2009b; Singleton et al. 2003). However, $\alpha$-synuclein, which typically accumulates in Lewy bodies (Spillantini et al. 1998), is not mutated in the large majority of PD patients. Nevertheless, numerous lines of mice overexpressing $\alpha$-synuclein have been generated using distinct promoters and transgenes (Fernagut and Chesselet 2004). These models use transgenes with mutations causing familial PD, the full-length protein, or truncated forms of the protein. Most recapitulate some but not all aspects of PD, and effects relevant to the disease are generally correlated to the levels of $\alpha$-synuclein expression (Magen and Chesselet 2010). Importantly, expression of transgenes is not limited to dopaminergic neurons but is defined by the nature of the genetic modification, i.e., promoter and genomic insertion site. However, a common advantage of these models, compared to pharmacological and toxicological models, is the slowly progressive accumulation of $\alpha$-synuclein, a typical feature of idiopathic PD. The main strength of $\alpha$-synuclein models is the ability to replicate $\alpha$-synuclein-positive inclusions (Table 2), although the typical fibrillar halo structure of Lewy bodies, observed in human PD, is not observed in the murine $\alpha$-synuclein-positive inclusions (Maries et al. 2003). A major limitation of $\alpha$-synuclein models is their inability to model cell loss in the substantia nigra pars compacta. Mice overexpressing wild-type human $\alpha$-synuclein exhibit reduced olfaction, autonomic dysfunction, $\alpha$-synuclein accumulation, and early motor deficits in the absence of nigrostriatal neurodegeneration (Chesselet et al. 2008; Fleming et al. 2004; Fleming et al. 2008; Rockenstein et al. 2002).

$\alpha$-Synuclein knockout mice are viable and show decreased striatal dopamine levels and reduced rearing. These findings may be explained by the hypothesis that $\alpha$-synuclein plays a role in synaptic vesicle function. Triple $\alpha \beta \gamma$-synuclein knockout mice present age-dependent synaptic and neuronal dysfunction, demonstrating that synucleins contribute to the long-term operation of the nervous system (Burre et al. 2010; Greten-Harrison et al. 2010). Conversely, mice overexpressing $\alpha$-synuclein develop intraneuronal inclusions and show decreased striatal dopamine levels, despite lacking nigral cell loss. However, mice overexpressing a double-mutated or a truncated form of $\alpha$-synuclein under the tyrosine hydroxylase (TH) promoter present a selective loss of nigrostriatal dopaminergic neurons. The double-mutated $\alpha$-synuclein variant (A30P/ A53T) used in one of these studies has never been described in humans (Thiruchelvam et al. 2004). In contrast, expression of $\mathrm{N}$-terminal $\alpha$-synuclein fragments, comparable to those used in the second study (Wakamatsu et al. 2008a), has been detected in PD brain extracts ( $\mathrm{Li}$ et al. 2005). In addition, the relevance of the A53T mutation in mouse models remains to be evaluated. Although the A53T mutation can cause PD in humans, threonine is the wild-type residue at this position in the murine sequence (Cabin et al. 2005; Larsen et al. 2009). Human A53T $\alpha$-synuclein, however, was described to be more toxic on an $\alpha$-synuclein-null background than on a murine wild-type background. This contrast between the protective effects of wild-type mouse $\alpha$-synuclein and the deteriorative effects of human A53T $\alpha$-synuclein on mice might be linked to the six other $\alpha$-synuclein amino acid differences between these two species (Cabin et al. 2005).

Recently, data from tyrosine hydroxylase (TH) promoter-controlled $\alpha$-synuclein-overexpressing mouse models led to the hypothesis that microglial activation is an early hallmark of PD (Su et al. 2008, 2009). Findings at the neurochemical and gene expression level suggest that $\alpha$-synuclein also influences dopamine metabolism (Miller et al. 2007; Richfield et al. 2002; Yu et al. 2008). In addition, TH promoter-controlled overexpression of the double-mutated $\alpha$-synuclein impairs the ubiquitin proteasome system in aged mice (Chen et al. 2006). The main limitation of this model is a spatially restricted pathology. This limitation can be circumvented, at least in part, by crossing $\alpha$-synuclein transgenic mice with mice lacking murine $\alpha$-synuclein. In this case, the absence of endogenous $\alpha$-synuclein appears to drive the aggregation of transgenic $\alpha$-synuclein throughout different brain regions (Prasad et al. 2011). In contrast, human Lewy body formation and $\alpha$-synuclein expression in neurites are widely distributed in both the central and peripheral nervous systems (Braak et al. 2003; Halliday et al. 2005).

Platelet-derived growth factor- $\beta$ (PDGF- $\beta$ ) promotercontrolled $\alpha$-synuclein-overexpressing mouse models aim to mimic the broad distribution of $\alpha$-synuclein pathology in humans (Masliah et al. 2000). Recent findings suggest that overexpression of A53T $\alpha$-synuclein affects neurogenesis 
Table 2 Alpha-synuclein models

\begin{tabular}{|c|c|c|c|c|c|c|c|c|c|c|}
\hline Model(s) & Promoter & Background & I & MS & NMS & $\mathrm{TH}$ & BG & SP & Age & Ref \\
\hline WT, A53T & PDGF- $\beta$ & $\mathrm{C} 57 \mathrm{BL} / 6 \times \mathrm{DBA} 2$ & $\mathrm{Y}$ & $\mathrm{Y}$ & NR & $\mathrm{Y}$ & $\mathrm{Y}$ & NR & $\mathrm{Y}$ & 1 \\
\hline WT & $\mathrm{KO}$ & C57BL/6 & NR & NR & NR & NR & NR & NR & NR & 2 \\
\hline WT & PDGF- $\beta$ & C57BL/6 & NR & NR & NR & NR & NR & $\mathrm{Y}$ & NR & 3 \\
\hline A53T & Mouse Thy-1 & C57BL/6 & $\mathrm{LN}$ & $\mathrm{Y}$ & NR & NR & $\mathrm{N}$ & NR & NR & 4 \\
\hline WT, A30P, A53T & Mouse Thy-1 & C57BL/6 & $\mathrm{Y}$ & Y & IFC & NR & $\mathrm{Y}$ & NR & $\mathrm{Y}$ & 5 \\
\hline$\underline{\mathrm{WT}},(\mathrm{A} 30 \mathrm{P})$ & Mouse Thy-1 & $\mathrm{C} 57 \mathrm{BL} / 6 \times \mathrm{DBA} 2$ & $\mathrm{Y}$ & Y & $\mathrm{Y}$ & $\mathrm{Y}$ & $\mathrm{Y}$ & $\mathrm{Y}$ & $\mathrm{N}$ & 6 \\
\hline Y39C & Mouse Thy-1 & $\mathrm{FVB} / \mathrm{N}$ & $\mathrm{Y}$ & $\mathrm{Y}$ & $\mathrm{CD}$ & $\mathrm{N}$ & $\mathrm{N}$ & $\mathrm{Y}$ & $\mathrm{Y}$ & 7 \\
\hline $\mathrm{A} 30 \mathrm{P}+\mathrm{A} 53 \mathrm{~T}$ & Human Thy-1 & $\mathrm{C} 57 \mathrm{BL} / 6 \times \mathrm{DBA} 2$ & $\mathrm{Y}$ & $\mathrm{Y}$ & $\mathrm{N}$ & $\mathrm{Y}$ & $\mathrm{Y}$ & $\mathrm{Y}$ & $\mathrm{N}$ & 8 \\
\hline (WT), (A30P), $\underline{\mathrm{A} 53 \mathrm{~T}}$ & Mouse prion & $\begin{array}{l}\mathrm{C} 3 \mathrm{H} / \mathrm{HeJ} \times \mathrm{C} 57 \mathrm{BL} / 6 \mathrm{~J} \\
\text { backcrossed into } \mathrm{C} 57 \mathrm{BL} / 6 \mathrm{~J} \\
\text { PARKIN KO }\end{array}$ & $\mathrm{Y}$ & Y & MD & $\mathrm{N}$ & $\mathrm{Y}$ & $\mathrm{N}$ & $\mathrm{Y}$ & 9 \\
\hline WT, A53T & Mouse prion & $\mathrm{C} 57 \mathrm{BL} / 6 \times \mathrm{C} 3 \mathrm{H}$ & $\mathrm{Y}$ & $\mathrm{Y}$ & RA & $\mathrm{N}$ & $\mathrm{Y}$ & $\mathrm{Y}$ & $\mathrm{N}$ & 10 \\
\hline (WT), A53T & Mouse prion & $\begin{array}{l}\mathrm{FVB} / \mathrm{N}, \mathrm{FVB} \times 129 \\
\alpha \text {-synuclein KO }\end{array}$ & $\mathrm{N}$ & $\mathrm{Y}$ & NR & NR & NR & $\mathrm{Y}$ & $\mathrm{N}$ & 11 \\
\hline (WT), A30P & Mouse prion & $\begin{array}{l}\text { C57BL/6J } \times \text { DBA2 } \\
\text { backcrossed into C57BL/6J }\end{array}$ & $\mathrm{N}$ & Y & ASP & $\mathrm{N}$ & NR & NR & $\mathrm{Y}$ & 12 \\
\hline WT, A30P, A53T & Hamster prion & $\mathrm{C} 57 \mathrm{BL} / 6 \mathrm{~J} \times \mathrm{SJL}$ & $\mathrm{N}$ & $\mathrm{Y}$ & NR & $\mathrm{N}$ & NR & $\mathrm{Y}$ & $\mathrm{Y}$ & 13 \\
\hline WT, A30P, A53T & Rat THP & Swiss Webster $\times$ C57BL/DBA & $\mathrm{N}$ & NR & NR & $\mathrm{N}$ & NR & NR & NR & 14 \\
\hline $\mathrm{WT}, \underline{\mathrm{A} 30 \mathrm{P}} \pm \underline{\mathrm{A} 53 \mathrm{~T}}$ & Rat THP & C57BL/6J & $\mathrm{N}$ & $\mathrm{Y}$ & NR & NR & NR & $\mathrm{Y}$ & $\mathrm{Y}$ & 15 \\
\hline Truncated (1-120) & Rat THP & $\begin{array}{l}\mathrm{C} 57 \mathrm{BL} / 6 \mathrm{~J} \times \mathrm{CBA} / \mathrm{ca} \\
\text { backcrossed into C57BL/6J, } \\
\alpha \text {-synuclein KO }\end{array}$ & $\mathrm{Y}$ & Y & NR & NR & $\mathrm{N}$ & $\mathrm{Y}$ & $\mathrm{Y}$ & 16 \\
\hline Truncated (1-130) & Rat THP & C57BL/6J & $\mathrm{N}$ & $\mathrm{N}$ & REB & $\mathrm{Y}$ & $\mathrm{Y}$ & $\mathrm{N}$ & $\mathrm{N}$ & 17 \\
\hline $\mathrm{A} 30 \mathrm{P}+\mathrm{A} 53 \mathrm{~T}$ & Chicken beta actin, BA & C57BL/6 & NR & NR & MD & $\mathrm{N}$ & $\mathrm{N}$ & NR & Y & 18 \\
\hline $\mathrm{A} 30 \mathrm{P}+\mathrm{A} 53 \mathrm{~T}$ & Mouse THP & C57BL/6 & NR & NR & MD & $\mathrm{N}$ & $\mathrm{N}$ & NR & $\mathrm{Y}$ & 19 \\
\hline $\mathrm{A} 30 \mathrm{P}+\mathrm{A} 53 \mathrm{~T}$ & Mouse prion & C57BL/6 & NR & NR & NR & NR & $\mathrm{N}$ & NR & NR & 20 \\
\hline WT, A30P, A53T & CaM-tTA (tet-off) & $\begin{array}{l}\text { C57BL/6 (WT and A30P), } \\
\text { C57BL/CH3 (WT and A53T) }\end{array}$ & $\mathrm{N}$ & $\mathrm{Y}$ & CD & NR & $\mathrm{Y}$ & $\mathrm{Y}$ & $\mathrm{Y}$ & 21 \\
\hline A30P & $\begin{array}{l}\text { KI in endogenous } \\
\alpha \text {-synuclein }\end{array}$ & C57BL/6 & NR & Y & NR & $\mathrm{RD}$ & NR & Y & Y & 22 \\
\hline Truncated (1-119) & Conditional ROSA26 & C57BL/6J & $\mathrm{N}$ & NR & NR & $\mathrm{RD}$ & $\mathrm{N}$ & NR & $\mathrm{N}$ & 23 \\
\hline A53T & Conditional ROSA26 & C57BL/6J & $\mathrm{N}$ & NR & NR & NR & $\mathrm{N}$ & NR & $\mathrm{N}$ & 23 \\
\hline WT, A30P, A53T & $\begin{array}{l}\text { Endogenous } \\
\alpha \text {-synuclein (BAC) }\end{array}$ & $\mathrm{FVB} / \mathrm{N} \times 129 \mathrm{~S} 6 / \mathrm{SvEvTac}$ & $\mathrm{N}$ & $\mathrm{Y}$ & $\mathrm{Y}$ & NS & $\mathrm{N}$ & Y & $\mathrm{N}$ & 24 \\
\hline
\end{tabular}

Alpha-synuclein models express truncated or full-length $\alpha$-synuclein with or without mutations. The expression of these constructs, in different mouse strains, is controlled by different promoters and causes distinct phenotypes. The models are grouped by project. Lines with a stronger phenotype are underlined and lines without phenotype are in parentheses

Age = age-related progression; ASP = affected synaptic plasticity; $\mathrm{BA}=$ beta-actin promoter; $\mathrm{BG}=$ neurodegeneration in the basal ganglia; $\mathrm{CD}=$ cognitive deficits; $\mathrm{I}=\alpha$-synuclein positive inclusions; IFC = impaired fear conditioning; LN $=$ Lewy-like neurites; MD $=$ mitochondrial deficits; $\mathrm{MS}=$ motor signs; $\mathrm{N}=$ no; $\mathrm{NMS}=$ nonmotor signs; $\mathrm{NR}=$ not reported; $\mathrm{NS}=$ not significant; RA = reduced anxiety; $\mathrm{RD}=$ reduced dopamine level; $\mathrm{REB}=$ reduced exploratory behavior; $\mathrm{SP}=$ slow progression; $\mathrm{TH}=$ reduced level of tyrosine hydroxylase; THP $=$ tyrosine hydroxylase promoter; $\mathrm{Y}=$ yes

References (Ref): 1 = Hashimoto et al. 2003; Koob et al. 2010; Masliah et al. 2000; Rockenstein et al. 2002; Winner et al. 2004; Winner et al. 2008; Yacoubian et al. 2008; 2 = Sharon et al. 2003; 3 = Liu P et al. Liu et al. 2010a, b; 4 = van der Putten et al. 2000; $5=$ Frasier et al. 2005; Freichel et al. 2007; Kahle et al. 2000; Neumann et al. 2002; Poon et al. 2005; Schell et al. 2009; 6 = Fernagut et al. 2007; Fleming et al. 2004; Fleming et al. 2006; Fleming et al. 2008; Koob et al. 2010; Rockenstein et al. 2002; Song et al. 2004; Wang et al. 2008; Watson et al. 2009; Wu et al. 2010; 7 = Zhou et al. 2008; 8 = Ikeda et al. 2009; Ono et al. 2009; $9=$ Lee et al. 2002; Martin et al. 2006; Miller et al. 2007; Unger et al. 2006; von Coelln et al. 2006; $10=$ Gao et al. 2008; George et al. 2008; Giasson et al. 2002; Graham and Sidhu 2010; Norris et al. 2007; Sotiriou et al. 2010; $11=$ Cabin et al. 2005; Gispert et al. 2003; 12 = Gureviciene et al. 2007; 2009; Oksman et al. 2009; Yavich et al. 2006; Yavich et al. 2005; 13 = Gomez-Isla et al. 2003; Nieto et al. 2006; 14 = Manning-Bog et al. 2003; Matsuoka et al. 2001; Yu et al. 2008; 15 = Chen et al. 2006; Miller et al. 2007; Richfield et al. 2002; Su et al. 2009; Su et al. 2008; Thiruchelvam et al. 2004; $16=$ Tofaris et al. 2006; $17=$ Wakamatsu et al. 2008a; Wakamatsu et al. 2008b; 18 = Maskri et al. 2004; Stichel et al. 2007; 19 = Maskri et al. 2004; Stichel et al. 2007; 20 = Maskri et al. 2004; $21=$ Lim et al. 2010; Marxreiter et al. 2009; Nuber et al. 2008; $22=$ Plaas et al. 2008; $23=$ Daher et al. 2009; $24=$ Kuo et al. 2010 
and proliferation of newly born neurons in the subventricular zone (Winner et al. 2004, 2008). Molecular analysis of mice with PDGF- $\beta$-controlled overexpression of $\alpha$-synuclein suggested that interactions between $\alpha$-synuclein, polyunsaturated fatty acids, and cholesterol accelerate $\alpha$-synuclein aggregation (Bieschke et al. 2006; Sharon et al. 2003). Koob et al. (2010) used this model to show that treatment with the cholesterol synthesis inhibitor lovastatin alleviates these alterations. In PDGF- $\beta / \alpha$-synuclein mice, gene expression is altered. However, neuronal death has not yet been reported in these mice (Yacoubian et al. 2008). Changes due to overexpression of $\alpha$-synuclein are restricted mainly to the olfactory bulb and the hippocampus, and deficits occur relatively late. Despite changes at the gene expression level, dopamine metabolism, TH terminals, and neurogenesis, no overt pathology of the nigrostriatal system or clinical hallmarks have been observed in PDGF- $\beta$ / $\alpha$-synuclein mice.

In contrast to PDGF- $\beta / \alpha$-synuclein models, prion protein promoter $\alpha$-synuclein models aim to study the effects of extremely high overexpression of $\alpha$-synuclein in neurons usually involved in PD, including neurons of the substantia nigra (Maskri et al. 2004). However, the translational relevance of these models, with typically severe motor deficits, is mitigated by high transgene expression in motor neurons of the spinal cord and brainstem, which confer behavioral deficits that are not characteristic for PD (Magen and Chesselet 2010). An additional drawback is the lack of cell loss in the substantia nigra and locus coeruleus.

Compared to the prion protein promoter, the Thy-1 promoter causes a more widespread expression of $\alpha$-synuclein, which is not restricted to catecholaminergic neurons (Rockenstein et al. 2002), and does not cause any motor neuron loss when used in C57BL/6 mice. Nigral cell loss was observed in only a few cases, but most of the studies found typical PD phenotypes such as loss of dopamine in the striatum, motor deficits, and nonmotor deficits (Fleming et al. 2004; Ikeda et al. 2009; Ono et al. 2009; van der Putten et al. 2000). These mice further develop an agedependent neurite terminal $\alpha$-synuclein pathology, suggesting that $\alpha$-synuclein is selectively phosphorylated in restricted brain regions (Schell et al. 2009). Some Thy1/ $\alpha$-synuclein mouse lines present early motor and nonmotor deficits equivalent to those in PD prior to clinical diagnosis, suggesting that these models could be useful for the study of preclinical PD stages and hence for translational research (Fernagut et al. 2007; Fleming et al. 2004, 2006, 2008; Koob et al. 2010; Song et al. 2004). However, other studies using Thy $1 / \alpha$-synuclein mouse lines demonstrated a much later onset, or even absence, of motor dysfunction (Freichel et al. 2007; Neumann et al. 2002; Zhou et al. 2008).
Models overexpressing $\alpha$-synuclein under the calcium/ calmodulin-dependent protein kinase II $\alpha(\mathrm{CaM})$ promoter were initially designed to study postnatal neurogenesis in the olfactory bulb and hippocampus. Conditional overexpression driven by the $\mathrm{CaM}$ promoter can be triggered by a tetracycline transactivator. The emergence of conditional transgenic models enables detailed investigation of the reversibility of $\alpha$-synuclein pathology, thereby helping to focus on therapeutic strategies that aim to regulate $\alpha$-synuclein expression at early stages of the disease (Lim et al. 2010; Marxreiter et al. 2009; Nuber et al. 2008). Recent models allow the control of gene expression in a regiondependent manner. One example is the Cre/loxP-based mouse model-expressing truncated $\mathrm{N}$-terminal $\alpha$-synuclein fragments-that shows reduced striatal dopamine levels but no neurodegeneration (Daher et al. 2009).

The most recently reported $\alpha$-synuclein mouse model expresses A53T $\alpha$-synuclein under a P1 artificial chromosome on an $\alpha$-synuclein-null background. These mice have early motor deficits but no $\alpha$-synuclein-positive inclusions, no loss of TH-positive cells in the substantia nigra, and no dopamine loss in the striatum. However, these mice have decreased colonic motility that may result from proteinase $\mathrm{K}$-resistant $\alpha$-synuclein aggregates found in neurons of the enteric nervous system. Olfactory function and cardiac innervation remain intact (Kuo et al. 2010). Consistently, this model could serve to investigate therapies for gastrointestinal dysfunction in early preclinical PD stages.

\section{PARKIN, PTEN-induced putative kinase 1 (PINK1),} and DJ1

In addition to the $\alpha$-synuclein model, other models of familial PD have been reported. Recessive mutations in PARKIN, PINK1, and DJI were mostly modeled using knockout strategies that result in the lack of the corresponding protein and, so far, to modest PD-associated deficits (Table 3).

The most frequent mutations causing early-onset recessive familial forms of PD occur in the PARKIN gene. PARKIN is an ubiquitin E3 ligase that ubiquitinates proteins to regulate a variety of cellular processes. Loss of E3 ligase activity is thought to play a pathogenic role in both inherited and sporadic PD (Dawson and Dawson 2010). More recently, PARKIN has been demonstrated to play a role in maintaining mitochondrial homeostasis through targeting damaged mitochondria for mitophagy (Tanaka 2010). PARKIN loss-of-function could thus lead to enhanced presence of dysfunctional mitochondria, a process that could contribute to PD pathogenesis. PARKIN knockout mice have been generated by deleting either exon 3 or 7 . These lines show mild, progressive motor deficits and premotor signs typical of PD, i.e., reduced dopamine 


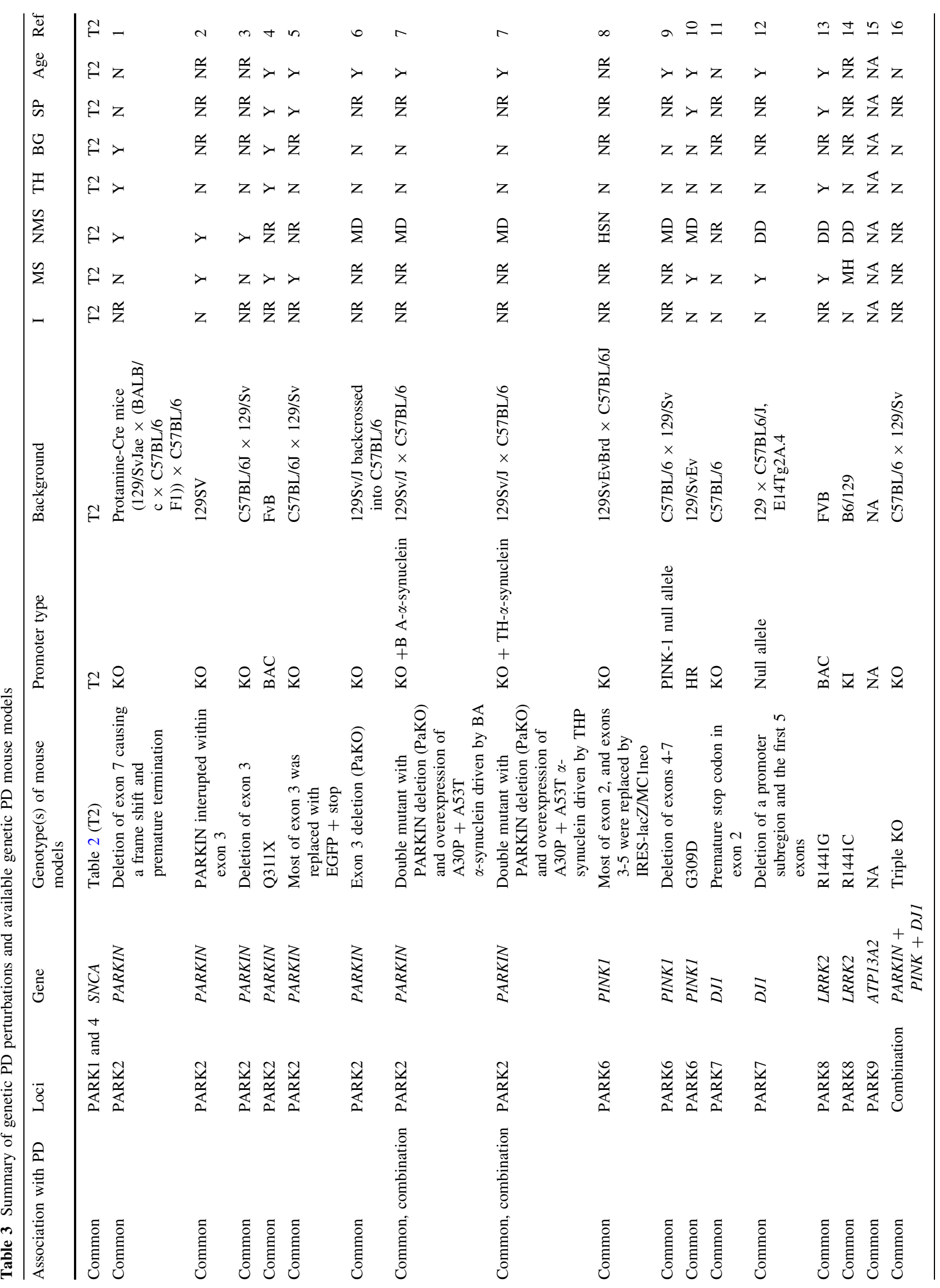




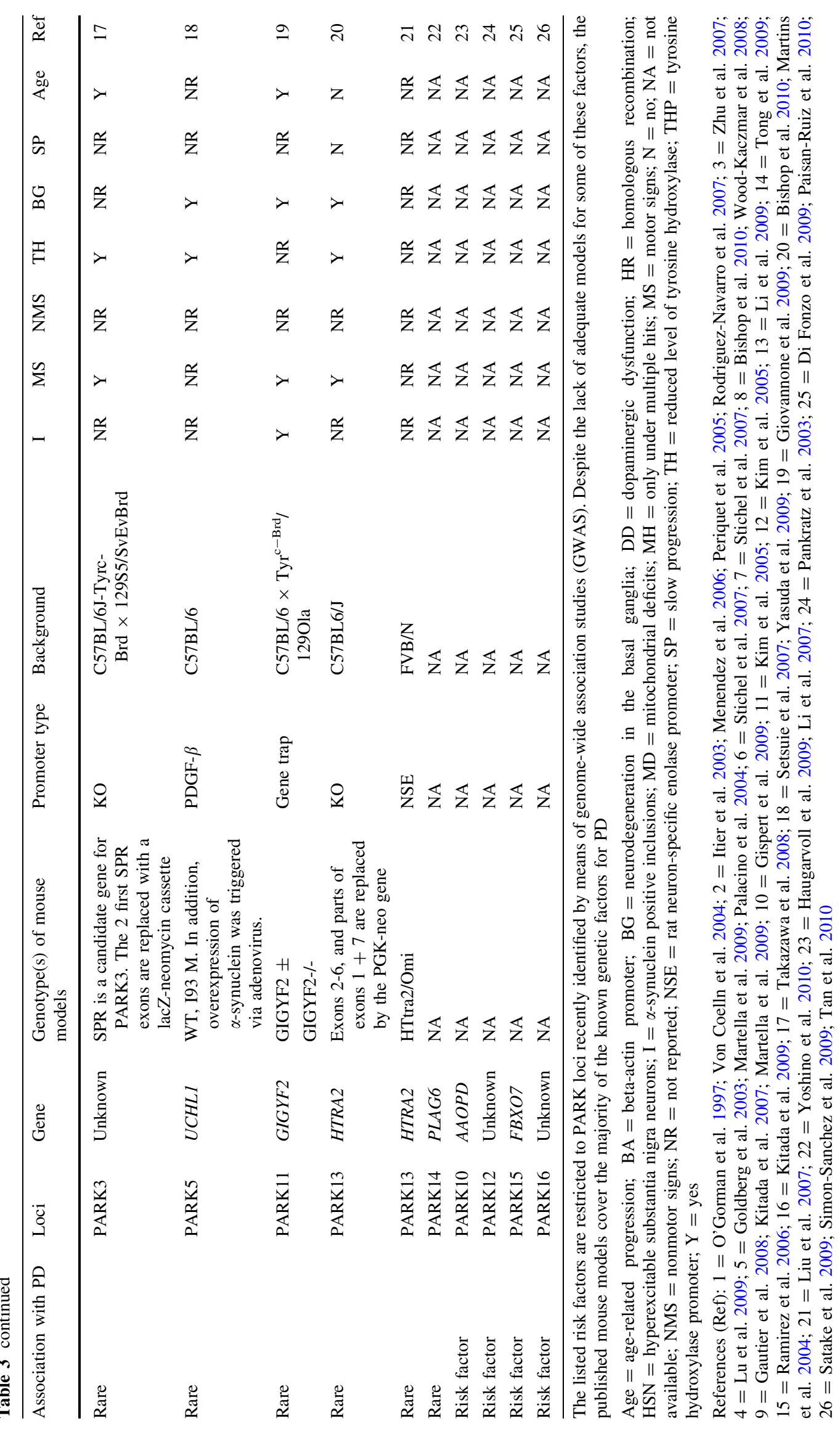


release, synaptic anomalies, mitochondrial damage, and increased oxidative stress. However, none of these models shows a progressive loss of nigrostriatal dopaminergic neurons (Goldberg et al. 2003; Itier et al. 2003; Martella et al. 2009; Palacino et al. 2004; Periquet et al. 2005; Rodriguez-Navarro et al. 2007; Stichel et al. 2007; Von Coelln et al. 2004; Zhu et al. 2007). Dopaminergic cell loss can be induced by exposure to the inflammatory stressor lipopolysaccharide (LPS) (Frank-Cannon et al. 2008), illustrating that PARKIN mutations may make dopaminergic neurons more vulnerable to environmental insults. Lu et al. (2009) investigated whether the PARKIN mutation Q311X exerts dominant toxicity on nigrostriatal dopaminergic neurons. The selective expression of this mutation in dopaminergic neurons does indeed cause progressive nigrostriatal dopaminergic cell loss, $\alpha$-synuclein pathology, and motor deficits (Lu et al. 2009). This implies that these mice provide a model for dopaminergic neuron death caused by PARKIN mutations.

Similar to PARKIN knockout mice, PINK1 and DJ1 mice have, so far, failed to reproduce canonical PD deficits. Similar observations were made in a triple transgenic model lacking PARKIN, PINK1, and DJI (Kitada et al. 2009). Without additional insults, PINK1 and DJ1 deficiency does not cause spontaneous loss of nigrostriatal dopaminergic neurons (Aron et al. 2010; Morais et al. 2009). However, most of these mice show reduced activity, increased oxidative stress, and increased vulnerability to mitochondrial toxins (Chen et al. 2005; Gautier et al. 2008; Gispert et al. 2009; Kim et al. 2005). Overall, recessive PD models appear to have potential for the modeling of environmental factors in familial forms of PD.

\section{Leucine-rich repeat kinase 2 (LRRK2)}

Dominant LRRK2 mutations have recently been identified as causes of familial PD. Heterozygote carriers can develop familial PD with characteristics similar to the sporadic disease forms (Cookson et al. 2008). However, penetrance is strongly age-dependent. At the age of 69 years, only $51 \%$ of carriers show signs of PD (Healy et al. 2008). Several mutations have been identified in human PD patients, the most frequent one being the G2019S mutation. Lin et al. (2009) generated LRRK2 knockout mice and transgenic mice with inducible overexpression of the human wild-type, the G2019S mutant, or the kinase domain-deleted $L R R K 2$. Neither deletion nor overexpression of these $L R R K 2$ constructs caused gross neurodegeneration. However, all three $L R R K 2$ constructs exacerbated the progression of human A53T $\alpha$-synuclein-induced neuropathology. Overexpression of $L R R K 2$ or its mutants impaired the structure and function of the Golgi complex and microtubule-based transport, resulting in a pathogenic somatic accumulation of $\alpha$-synuclein (Lin et al. 2009).

Later, Li et al. (2010) characterized two bacterial artificial chromosome (BAC) transgenic mouse strains overexpressing either wild-type or G2019S-mutated LRRK2. Transgenic mice overexpressing wild-type LRRK2 presented an elevated striatal dopamine release, were hyperactive, and showed enhanced motor performance. In contrast, mice expressing the G2019S mutant showed an age-dependent decrease in striatal dopamine content ( $\mathrm{Li}$ et al. 2010). Melrose et al. (2010) also reported impaired dopaminergic neurotransmission in BAC LRRK2 mice. In G2019S mice, these changes were linked to a modified localization and phosphorylation of the microtubule-binding protein tau (Melrose et al. 2010). A more recent study that also used mice that overexpress G2019S LRRK2 by using a BAC construct, analyzed adult neurogenesis (Winner et al. 2011). The proliferation and survival of newly generated cells was significantly decreased by the overexpression of G2019S LRRK2, and newly generated neurons exhibited reduced dendritic arborization and fewer spines (Winner et al. 2011).

Mice harboring the R1441G mutation develop a strong behavioral phenotype and an altered dopamine release ( $\mathrm{Li}$ et al. 2009). In contrast, mice harboring the R1441C mutation do not present prominent motor defects but only dopaminergic deficits (Tong et al. 2009). LRRK2 seems to be involved in both familial and idiopathic PD. Therefore, LRRK2 is a very attractive target for therapeutic intervention (Paisan-Ruiz et al. 2004; Satake et al. 2009; Simon-Sanchez et al. 2009; Zimprich et al. 2004). The value of LRRK2 mouse models for translational research in this direction remains to be evaluated, but primary results indicate that these models might be useful for analyzing impaired cellular dynamics that cause dopaminergic dysfunction.

\section{Models for other network perturbations in PD}

Genetic models of PD are widely used. However, only a few of these models reproduce the cardinal features of the disease. Most strikingly, most genetically altered mice do not show extensive or progressive loss of nigrostriatal dopaminergic neurons (Chesselet et al. 2008). It is reasonable to assume that distinct causal factors leading to neurodegeneration in PD perturb converging molecular or cellular pathways. In fact, the concept of PD as network perturbation might be useful to guide translational research (Del Sol et al. 2010). Consequently, models for network perturbations are relevant to translational research in PD. These include the above-mentioned genetic and toxic models as well as models for genetic risk factors and 
models for disease pathway perturbations such as mitochondrial dysfunction (Wellstead and Cloutier 2011).

Aphakia and weaver mice

Besides blindness, the so-called aphakia mice-lacking the transcription factor Pitx3-present complete loss of nigrostriatal dopaminergic neurons during early postnatal development. This model does not clearly reproduce progressive loss of dopaminergic neurons in PD, yet it is useful to validate behavioral mouse tests for dopaminergic deficits (Hwang et al. 2005). Pitx3 polymorphisms have been associated with an increased risk for PD (Haubenberger et al. 2011) and may therefore be involved in human PD. In addition, Pitx 3 may directly regulate expression of the vesicular monoamine transporter (VMAT) and the dopamine transporter (DAT), two genes associated with increased risk for PD (Hwang et al. 2009; Ritz et al. 2009; Takahashi et al. 1997).

In turn, weaver mutants carry a mutation in the G-protein-coupled inwardly rectifying channel (GIRK2) (Guatteo et al. 2004). An important characteristic of these mice for research in PD is a gradual nigrostriatal dopaminergic neurodegeneration (Cavalcanti-Kwiatkoski et al. 2010).

\section{VMAT}

Mice with reduced expression of VMAT, member 2 (VMAT2) have reduced monoamine storage capacity and present both a progressive loss of striatal dopamine and L-DOPA-responsive motor deficits. In addition, VMAT2deficient mice present progressive nonmotor signs such as progressive deficits in olfactory discrimination, delayed gastric emptying, altered sleep latency, and age-dependent depressive behavior. This model might be valuable for translational research toward restoration of monoamine dysfunction at early nonmotor stages of PD (Taylor et al. 2009).

\section{MitoPark mice}

The so-called MitoPark mouse-lacking the mitochondrial transcription factor A (TFAM) - is a model of mitochondrial dysfunction in dopaminergic midbrain neurons. These mice exhibit an adult-onset progressive loss of nigrostriatal dopaminergic neurons, accompanied by the formation of intraneuronal inclusions (Ekstrand and Galter 2009; Ekstrand et al. 2007). As in human PD, impaired nigrostriatal function precedes the onset of motor deficits, and L-DOPA administration improves motor dysfunction (Galter et al. 2010; Good et al. 2011). MitoPark mice may provide a useful model for investigating neuroprotective strategies (Harvey et al. 2008). However, is it not yet fully understood whether mitochondrial dysfunction is the cause of PD or whether it is a consequence of other perturbations within a cascade of pathogenic events.

\section{Aging}

Aging is the primary risk factor for the development of PD. In fact, there are many parallels between normal aging and early stages of PD. In normal aging, the striatal dopamine levels are reduced and there is loss of dopaminergic nigral neurons. These losses are associated with age-related increases in $\alpha$-synuclein (Irwin et al. 1992; McNeill and Koek 1990). Collectively, these findings suggest that aged animals represent a useful model for the evaluation of therapies aimed at the earliest stages of PD and that it might be valuable to rethink aged animals' validity for translational research in PD.

\section{Future challenges and needs in PD animal models and translational research}

Today, we understand that the prodrome of PD can be initiated by genetic and environmental factors. However, the total number of involved genes is not yet known. In addition, different genetic backgrounds, for instance, between different consomic mouse strains, can influence the phenotypic outcome in animal models (Nishi et al. 2010). One challenge is, therefore, to better understand the complex relationships between genetic factors and PD onset and manifestation. One possibility is to identify regions of the genome that play a role in complex PD-related traits. In the case of PD, quantitative trait loci (QTLs) could be used to map the genes underlying parkinsonian phenotypes or susceptibility to PD. The Complex Trait Consortium has provided a reference panel of recombinant inbred strains designed for QTL analysis (Churchill et al. 2004; Vogel 2003). These congenic mouse strains, generated by mating distinct inbred strains and backcrossing the descendants, harbor nearly identical genomes. The resulting set of populations allows the analysis of the effects of different genetic backgrounds. The already existing genetic PD mouse models, in contrast, are designed to analyze the role of isolated genetic loci on a fixed background. Recently, GWAS aimed to better understand the genetic basis underlying PD. Both QTL analysis and whole-genome sequencing are powerful complementary tools for proceeding with these studies.

Future therapeutic interventions will likely aim at interrupting the progression of molecular and pathological prodromes. However, the causal cascade of pathogenic events is not yet fully understood. To improve the understanding of early pathogenesis, it will be necessary to 
analyze the temporal and causal coupling between events at the molecular, cellular, and organism scales. Furthermore, the history of translational research in well-studied diseases (e.g., Alzheimer disease) has demonstrated that findings from mouse models may not always be extrapolated to humans (Van Dam and De Deyn 2011). The validity of animal models of human diseases will therefore need to be evaluated. Of great importance, biomarkers found in animal models might help improve clinical risk evaluation and early diagnosis. Furthermore, biomarkers will allow us to empirically choose the most adequate animal models for specific questions in translational research (Srivastava et al. 2010). Novel techniques like live cell imaging and nanosurgery in the living mouse brain (Mascaro et al. 2010), progress in the development of epigenetic analysis tools, and reduced costs for omics analysis will help in the investigation of the complexity underlying PD. The complex relationships between multiple scales and evaluation of model relevance for clinical research will require new tools for the analysis of complex biological systems, i.e., systems biology, computational biology, and interdisciplinary cooperation. These tools should be suitable for developing translational research into a predictive, preventive, personalized, and participatory medicine (Auffray et al. 2010). An important step on the way to achieve personalized medicine will be to rank the potential of therapeutic strategies per disease state. In addition to mouse models, other animal models, including other rodents, primates, Drosophila melanogaster, Caenorhabditis elegans, and Saccharomyces cerevisiae (Hirth 2010; Nass et al. 2008; Witt and Flower 2006) as well as cellular models, should be considered. The adequate choice of models is critical for the outcome of translational research.

\section{Conclusion}

It is broadly accepted that current PD mouse models do not adequately present typical sets of symptoms characteristic of human PD. The striking differences between brain size and complexity between rodents and humans limit the direct translation of the experimental results to the clinic. Model and species properties determine the characteristics of the syndrome. Full reproduction of neuropathological and clinical PD manifestations is not expected in the mouse. However, a useful model should at least be of mechanistic relevance, thereby allowing potential therapeutic testing. The awareness that many mouse models show premotor symptoms of PD raises the possibility of development of novel treatments. However, none of the available models accurately recapitulates the complex and progressive pathology that characterizes human PD. These important shortcomings must be taken into account when translating information from the laboratory to the clinic. However, it is too simple to argue that the lack of reliable models for preclinical testing undermines investigations in clinical trials. An appropriate model should be chosen after considering the question to be answered. The perfect model that fits all requirements does not exist. However, some of the current models allow us to analyze precise questions within the PD disease spectrum. At present, preclinical models and models to evaluate enteric signs, nigrostriatal neurodegeneration, the multiple hits hypothesis, and acute motor dysfunction, among others, are available. In the past, translational research has advanced using appropriate models to aid the development of deep-brain stimulations and L-DOPA treatments. The current trend in translational $\mathrm{PD}$ research is neuroprotection or reversion of neurodegeneration. This endeavor requires models that reproduce early pathogenic events such as those observed in transgenic models. Better clinical PD stratification and identification of triggering environmental factors will further increase the demand for targeted models. The need for distinct model platforms and for the development of targeted therapeutic interventions will grow with our knowledge on PD etiology and stratification.

Acknowledgments We thank Dr. Manuel Buttini for insightful discussions and for helpful comments on the manuscript.

Open Access This article is distributed under the terms of the Creative Commons Attribution Noncommercial License which permits any noncommercial use, distribution, and reproduction in any medium, provided the original author(s) and source are credited.

\section{References}

Ahn TB, Kim SY, Kim JY, Park SS, Lee DS, Min HJ, Kim YK, Kim SE, Kim JM, Kim HJ et al (2008) alpha-Synuclein gene duplication is present in sporadic Parkinson disease. Neurology 70:43-49

Andersen JK (2009) Arvid Carlsson: an early pioneer in translational medicine. Sci Transl Med 1:2ps3

Anderson G, Noorian AR, Taylor G, Anitha M, Bernhard D, Srinivasan S, Greene JG (2007) Loss of enteric dopaminergic neurons and associated changes in colon motility in an MPTP mouse model of Parkinson's disease. Exp Neurol 207:4-12

Aron L, Klein P, Pham TT, Kramer ER, Wurst W, Klein R (2010) Pro-survival role for Parkinson's associated gene DJ-1 revealed in trophically impaired dopaminergic neurons. PLoS Biol 8:e1000349

Auffray C, Charron D, Hood L (2010) Predictive, preventive, personalized and participatory medicine: back to the future. Genome Med 2:57

Beal MF, Matthews RT, Tieleman A, Shults CW (1998) Coenzyme Q10 attenuates the 1-methyl-4-phenyl-1, 2, 3, tetrahydropyridine (MPTP) induced loss of striatal dopamine and dopaminergic axons in aged mice. Brain Res 783:109-114

Betarbet R, Sherer TB, MacKenzie G, Garcia-Osuna M, Panov AV, Greenamyre JT (2000) Chronic systemic pesticide exposure 
reproduces features of Parkinson's disease. Nat Neurosci 3: 1301-1306

Bezard E, Dovero S, Bioulac B, Gross CE (1997) Kinetics of nigral degeneration in a chronic model of MPTP-treated mice. Neurosci Lett 234:47-50

Bezard E, Dovero S, Prunier C, Ravenscroft P, Chalon S, Guilloteau D, Crossman AR, Bioulac B, Brotchie JM, Gross CE (2001) Relationship between the appearance of symptoms and the level of nigrostriatal degeneration in a progressive 1-methyl-4-phenyl1, 2, 3, 6-tetrahydropyridine-lesioned macaque model of Parkinson's disease. J Neurosci 21:6853-6861

Bieschke J, Zhang Q, Bosco DA, Lerner RA, Powers ET, Wentworth P Jr, Kelly JW (2006) Small molecule oxidation products trigger disease-associated protein misfolding. Acc Chem Res 39:611619

Bishop MW, Chakraborty S, Matthews GA, Dougalis A, Wood NW, Festenstein R, Ungless MA (2010) Hyperexcitable substantia nigra dopamine neurons in PINK1- and HtrA2/Omi-deficient mice. J Neurophysiol 104:3009-3020

Bove J, Prou D, Perier C, Przedborski S (2005) Toxin-induced models of Parkinson's disease. NeuroRx 2:484-494

Braak H, Del Tredici K, Rub U, de Vos RA, Jansen Steur EN, Braak E (2003) Staging of brain pathology related to sporadic Parkinson's disease. Neurobiol Aging 24:197-211

Burre J, Sharma M, Tsetsenis T, Buchman V, Etherton MR, Sudhof TC (2010) Alpha-synuclein promotes SNARE-complex assembly in vivo and in vitro. Science 329:1663-1667

Cabin DE, Gispert-Sanchez S, Murphy D, Auburger G, Myers RR, Nussbaum RL (2005) Exacerbated synucleinopathy in mice expressing A53T SNCA on a Snca null background. Neurobiol Aging 26:25-35

Carlsson A, Lindqvist M, Magnusson T (1957) 3, 4-Dihydroxyphenylalanine and 5-hydroxytryptophan as reserpine antagonists. Nature 180:1200

Cavalcanti-Kwiatkoski R, Raisman-Vozari R, Ginestet L, Del Bel E (2010) Altered expression of neuronal nitric oxide synthase in weaver mutant mice. Brain Res 1326:40-50

Chartier-Harlin MC, Kachergus J, Roumier C, Mouroux V, Douay X, Lincoln S, Levecque C, Larvor L, Andrieux J, Hulihan M et al (2004) Alpha-synuclein locus duplication as a cause of familial Parkinson's disease. Lancet 364:1167-1169

Chaudhuri KR, Healy DG, Schapira AH (2006) Non-motor symptoms of Parkinson's disease: diagnosis and management. Lancet Neurol 5:235-245

Chen L, Cagniard B, Mathews T, Jones S, Koh HC, Ding Y, Carvey PM, Ling Z, Kang UJ, Zhuang X (2005) Age-dependent motor deficits and dopaminergic dysfunction in DJ-1 null mice. J Biol Chem 280:21418-21426

Chen L, Thiruchelvam MJ, Madura K, Richfield EK (2006) Proteasome dysfunction in aged human alpha-synuclein transgenic mice. Neurobiol Dis 23:120-126

Chesselet MF, Fleming S, Mortazavi F, Meurers B (2008) Strengths and limitations of genetic mouse models of Parkinson's disease. Parkinsonism Relat Disord 14(Suppl 2):S84-S87

Churchill GA, Airey DC, Allayee H, Angel JM, Attie AD, Beatty J, Beavis WD, Belknap JK, Bennett B, Berrettini W et al (2004) The Collaborative Cross, a community resource for the genetic analysis of complex traits. Nat Genet 36:1133-1137

Cookson MR, Hardy J, Lewis PA (2008) Genetic neuropathology of Parkinson's disease. Int J Clin Exp Pathol 1:217-231

D'Costa DF, Sheehan LJ, Phillips PA, Moore-Smith B (1995) The levodopa test in Parkinson's disease. Age Ageing 24:210-212

Daher JP, Ying M, Banerjee R, McDonald RS, Hahn MD, Yang L, Flint Beal M, Thomas B, Dawson VL, Dawson TM et al (2009) Conditional transgenic mice expressing $\mathrm{C}$-terminally truncated human alpha-synuclein (alphaSyn119) exhibit reduced striatal dopamine without loss of nigrostriatal pathway dopaminergic neurons. Mol Neurodegener 4:34

Davis GC, Williams AC, Markey SP, Ebert MH, Caine ED, Reichert CM, Kopin IJ (1979) Chronic Parkinsonism secondary to intravenous injection of meperidine analogues. Psychiatry Res $1: 249-254$

Dawson TM, Dawson VL (2010) The role of parkin in familial and sporadic Parkinson's disease. Mov Disord 25(Suppl 1):S32-S39

Del Sol A, Balling R, Hood L, Galas D (2010) Diseases as network perturbations. Curr Opin Biotechnol 21:566-571

Di Fonzo A, Dekker MC, Montagna P, Baruzzi A, Yonova EH, Correia Guedes L, Szczerbinska A, Zhao T, Dubbel-Hulsman LO, Wouters $\mathrm{CH}$ et al (2009) FBXO7 mutations cause autosomal recessive, early-onset parkinsonian-pyramidal syndrome. Neurology 72:240-245

Ekstrand MI, Galter D (2009) The MitoPark Mouse - an animal model of Parkinson's disease with impaired respiratory chain function in dopamine neurons. Parkinsonism Relat Disord 15(Suppl 3): S185-S188

Ekstrand MI, Terzioglu M, Galter D, Zhu S, Hofstetter C, Lindqvist E, Thams S, Bergstrand A, Hansson FS, Trifunovic A et al (2007) Progressive parkinsonism in mice with respiratory-chaindeficient dopamine neurons. Proc Natl Acad Sci USA 104:13251330

Emborg ME (2004) Evaluation of animal models of Parkinson's disease for neuroprotective strategies. J Neurosci Methods 139: 121-143

Fearnley JM, Lees AJ (1991) Ageing and Parkinson's disease: substantia nigra regional selectivity. Brain 114(Pt 5):2283-2301

Fernagut PO, Chesselet MF (2004) Alpha-synuclein and transgenic mouse models. Neurobiol Dis 17:123-130

Fernagut PO, Hutson CB, Fleming SM, Tetreaut NA, Salcedo J, Masliah E, Chesselet MF (2007) Behavioral and histopathological consequences of paraquat intoxication in mice: effects of alpha-synuclein over-expression. Synapse 61:991-1001

Fleming SM, Salcedo J, Fernagut PO, Rockenstein E, Masliah E, Levine MS, Chesselet MF (2004) Early and progressive sensorimotor anomalies in mice overexpressing wild-type human alpha-synuclein. J Neurosci 24:9434-9440

Fleming SM, Salcedo J, Hutson CB, Rockenstein E, Masliah E, Levine MS, Chesselet MF (2006) Behavioral effects of dopaminergic agonists in transgenic mice overexpressing human wildtype alpha-synuclein. Neuroscience 142:1245-1253

Fleming SM, Tetreault NA, Mulligan CK, Hutson CB, Masliah E, Chesselet MF (2008) Olfactory deficits in mice overexpressing human wildtype alpha-synuclein. Eur J Neurosci 28:247-256

Forno LS (1996) Neuropathology of Parkinson's disease. J Neuropathol Exp Neurol 55:259-272

Frank-Cannon TC, Tran T, Ruhn KA, Martinez TN, Hong J, Marvin M, Hartley M, Trevino I, O'Brien DE, Casey B et al (2008) Parkin deficiency increases vulnerability to inflammation-related nigral degeneration. J Neurosci 28:10825-10834

Frasier M, Walzer M, McCarthy L, Magnuson D, Lee JM, Haas C, Kahle P, Wolozin B (2005) Tau phosphorylation increases in symptomatic mice overexpressing A30P alpha-synuclein. Exp Neurol 192:274-287

Freichel C, Neumann M, Ballard T, Muller V, Woolley M, Ozmen L, Borroni E, Kretzschmar HA, Haass C, Spooren W et al (2007) Age-dependent cognitive decline and amygdala pathology in alpha-synuclein transgenic mice. Neurobiol Aging 28:1421-1435

Fujishiro H, Frigerio R, Burnett M, Klos KJ, Josephs KA, Delledonne A, Parisi JE, Ahlskog JE, Dickson DW (2008) Cardiac sympathetic denervation correlates with clinical and pathologic stages of Parkinson's disease. Mov Disord 23:1085-1092

Galter D, Pernold K, Yoshitake T, Lindqvist E, Hoffer B, Kehr J, Larsson NG, Olson L (2010) MitoPark mice mirror the slow 
progression of key symptoms and L-DOPA response in Parkinson's disease. Genes Brain Behav 9:173-181

Gao HM, Kotzbauer PT, Uryu K, Leight S, Trojanowski JQ, Lee VM (2008) Neuroinflammation and oxidation/nitration of alphasynuclein linked to dopaminergic neurodegeneration. J Neurosci 28:7687-7698

Gash DM, Rutland K, Hudson NL, Sullivan PG, Bing G, Cass WA, Pandya JD, Liu M, Choi DY, Hunter RL et al (2008) Trichloroethylene: Parkinsonism and complex 1 mitochondrial neurotoxicity. Ann Neurol 63:184-192

Gasser T (2009a) Genomic and proteomic biomarkers for Parkinson disease. Neurology 72:S27-S31

Gasser T (2009b) Molecular pathogenesis of Parkinson disease: insights from genetic studies. Expert Rev Mol Med 11:e22

Gautier CA, Kitada T, Shen J (2008) Loss of PINK1 causes mitochondrial functional defects and increased sensitivity to oxidative stress. Proc Natl Acad Sci USA 105:11364-11369

George S, van den Buuse M, San Mok S, Masters CL, Li QX, Culvenor JG (2008) Alpha-synuclein transgenic mice exhibit reduced anxiety-like behaviour. Exp Neurol 210:788-792

Ghosh A, Roy A, Matras J, Brahmachari S, Gendelman HE, Pahan K (2009) Simvastatin inhibits the activation of p21ras and prevents the loss of dopaminergic neurons in a mouse model of Parkinson's disease. J Neurosci 29:13543-13556

Giasson BI, Duda JE, Quinn SM, Zhang B, Trojanowski JQ, Lee VM (2002) Neuronal alpha-synucleinopathy with severe movement disorder in mice expressing A53T human alpha-synuclein. Neuron 34:521-533

Giovanni A, Sieber BA, Heikkila RE, Sonsalla PK (1994a) Studies on species sensitivity to the dopaminergic neurotoxin 1-methyl-4phenyl-1, 2, 3, 6-tetrahydropyridine. Part 1: Systemic administration. J Pharmacol Exp Ther 270:1000-1007

Giovanni A, Sonsalla PK, Heikkila RE (1994b) Studies on species sensitivity to the dopaminergic neurotoxin 1-methyl-4-phenyl-1, 2, 3, 6-tetrahydropyridine. Part 2: Central administration of 1-methyl-4-phenylpyridinium. J Pharmacol Exp Ther 270:1008 1014

Giovannone B, Tsiaras WG, de la Monte S, Klysik J, Lautier C, Karashchuk G, Goldwurm S, Smith RJ (2009) GIGYF2 gene disruption in mice results in neurodegeneration and altered insulin-like growth factor signaling. Hum Mol Genet 18:4629 4639

Gispert S, Del Turco D, Garrett L, Chen A, Bernard DJ, HammClement J, Korf HW, Deller T, Braak H, Auburger G et al (2003) Transgenic mice expressing mutant A53T human alpha-synuclein show neuronal dysfunction in the absence of aggregate formation. Mol Cell Neurosci 24:419-429

Gispert S, Ricciardi F, Kurz A, Azizov M, Hoepken HH, Becker D, Voos W, Leuner K, Muller WE, Kudin AP et al (2009) Parkinson phenotype in aged PINK1-deficient mice is accompanied by progressive mitochondrial dysfunction in absence of neurodegeneration. PLoS One 4:e5777

Goldberg MS, Fleming SM, Palacino JJ, Cepeda C, Lam HA, Bhatnagar A, Meloni EG, Wu N, Ackerson LC, Klapstein GJ et al (2003) Parkin-deficient mice exhibit nigrostriatal deficits but not loss of dopaminergic neurons. J Biol Chem 278: 43628-43635

Goldman SM (2010) Trichloroethylene and Parkinson's disease: dissolving the puzzle. Expert Rev Neurother 10:835-837

Gomez-Isla T, Irizarry MC, Mariash A, Cheung B, Soto O, Schrump S, Sondel J, Kotilinek L, Day J, Schwarzschild MA et al (2003) Motor dysfunction and gliosis with preserved dopaminergic markers in human alpha-synuclein A30P transgenic mice. Neurobiol Aging 24:245-258

Good CH, Hoffman AF, Hoffer BJ, Chefer VI, Shippenberg TS, Backman CM, Larsson NG, Olson L, Gellhaar S, Galter D et al
(2011) Impaired nigrostriatal function precedes behavioral deficits in a genetic mitochondrial model of Parkinson's disease. FASEB J 25(4):1333-1344

Graham DR, Sidhu A (2010) Mice expressing the A53T mutant form of human alpha-synuclein exhibit hyperactivity and reduced anxiety-like behavior. J Neurosci Res 88:1777-1783

Greffard S, Verny M, Bonnet AM, Beinis JY, Gallinari C, Meaume S, Piette F, Hauw JJ, Duyckaerts C (2006) Motor score of the Unified Parkinson Disease Rating Scale as a good predictor of Lewy body-associated neuronal loss in the substantia nigra. Arch Neurol 63:584-588

Greten-Harrison B, Polydoro M, Morimoto-Tomita M, Diao L, Williams AM, Nie EH, Makani S, Tian N, Castillo PE, Buchman VL et al (2010) alphabetagamma-Synuclein triple knockout mice reveal age-dependent neuronal dysfunction. Proc Natl Acad Sci USA 107:19573-19578

Guatteo E, Bengtson CP, Bernardi G, Mercuri NB (2004) Voltagegated calcium channels mediate intracellular calcium increase in weaver dopaminergic neurons during stimulation of D2 and GABAB receptors. J Neurophysiol 92:3368-3374

Guehl D, Bezard E, Dovero S, Boraud T, Bioulac B, Gross C (1999) Trichloroethylene and parkinsonism: a human and experimental observation. Eur J Neurol 6:609-611

Gureviciene I, Gurevicius K, Tanila H (2007) Role of alpha-synuclein in synaptic glutamate release. Neurobiol Dis 28:83-89

Gureviciene I, Gurevicius K, Tanila H (2009) Aging and alphasynuclein affect synaptic plasticity in the dentate gyrus. J Neural Transm 116:13-22

Halliday GM, Ophof A, Broe M, Jensen PH, Kettle E, Fedorow H, Cartwright MI, Griffiths FM, Shepherd CE, Double KL (2005) Alpha-synuclein redistributes to neuromelanin lipid in the substantia nigra early in Parkinson's disease. Brain 128:2654 2664

Hamani C, Nobrega JN, Lozano AM (2010) Deep brain stimulation in clinical practice and in animal models. Clin Pharmacol Ther 88:559-562

Harvey BK, Wang Y, Hoffer BJ (2008) Transgenic rodent models of Parkinson's disease. Acta Neurochir Suppl 101:89-92

Hashimoto M, Rockenstein E, Masliah E (2003) Transgenic models of alpha-synuclein pathology: past, present, and future. Ann N Y Acad Sci 991:171-188

Haubenberger D, Reinthaler E, Mueller JC, Pirker W, Katzenschlager R, Froehlich R, Bruecke T, Daniel G, Auff E, Zimprich A (2011) Association of transcription factor polymorphisms PITX3 and EN1 with Parkinson's disease. Neurobiol Aging 32:302-307

Haugarvoll K, Toft M, Skipper L, Heckman MG, Crook JE, Soto A, Ross OA, Hulihan MM, Kachergus JM, Sando SB et al (2009) Fine-mapping and candidate gene investigation within the PARK10 locus. Eur J Hum Genet 17:336-343

Hawkes CH (2008) The prodromal phase of sporadic Parkinson's disease: does it exist and if so how long is it? Mov Disord 23: 1799-1807

Hawkes CH, Del Tredici K, Braak H (2010) A timeline for Parkinson's disease. Parkinsonism Relat Disord 16:79-84

Healy DG, Falchi M, O'Sullivan SS, Bonifati V, Durr A, Bressman S, Brice A, Aasly J, Zabetian CP, Goldwurm S et al (2008) Phenotype, genotype, and worldwide genetic penetrance of LRRK2-associated Parkinson's disease: a case-control study. Lancet Neurol 7:583-590

Hirth F (2010) Drosophila melanogaster in the study of human neurodegeneration. CNS Neurol Disord Drug Targets 9:504-523

Hwang DY, Fleming SM, Ardayfio P, Moran-Gates T, Kim H, Tarazi FI, Chesselet MF, Kim KS (2005) 3, 4-Dihydroxyphenylalanine reverses the motor deficits in Pitx3-deficient aphakia mice: behavioral characterization of a novel genetic model of Parkinson's disease. J Neurosci 25:2132-2137 
Hwang DY, Hong S, Jeong JW, Choi S, Kim H, Kim J, Kim KS (2009) Vesicular monoamine transporter 2 and dopamine transporter are molecular targets of Pitx3 in the ventral midbrain dopamine neurons. J Neurochem 111:1202-1212

Ibanez P, Bonnet AM, Debarges B, Lohmann E, Tison F, Pollak P, Agid Y, Durr A, Brice A (2004) Causal relation between alphasynuclein gene duplication and familial Parkinson's disease. Lancet 364:1169-1171

Ikeda M, Kawarabayashi T, Harigaya Y, Sasaki A, Yamada S, Matsubara E, Murakami T, Tanaka Y, Kurata T, Wuhua X et al (2009) Motor impairment and aberrant production of neurochemicals in human alpha-synuclein A30P + A53T transgenic mice with alpha-synuclein pathology. Brain Res 1250:232-241

Inden M, Kitamura Y, Abe M, Tamaki A, Takata K, Taniguchi T (2011) Parkinsonian rotenone mouse model: reevaluation of long-term administration of rotenone in C57BL/6 mice. Biol Pharm Bull 34:92-96

International Parkinson Disease Genomics Consortium, Nalls MA, Plagnol V, Hernandez DG, Sharma M, Sheerin UM, Saad M, Simón-Sánchez J, Schulte C, Lesage S, Sveinbjörnsdóttir S, Stefánsson K, Martinez M, Hardy J, Heutink P, Brice A, Gasser T, Singleton AB, Wood NW (2011) Imputation of sequence variants for identification of genetic risks for Parkinson's disease: a meta-analysis of genome-wide association studies. Lancet 377(9766):641-649

Irwin I, Finnegan KT, Delanney LE, Di Monte D, Langston JW (1992) The relationships between aging, monoamine oxidase, striatal dopamine and the effects of MPTP in C57BL/6 mice: a critical reassessment. Brain Res 572:224-231

Isaias IU, Antonini A (2010) Single-photon emission computed tomography in diagnosis and differential diagnosis of Parkinson's disease. Neurodegener Dis 7:319-329

Itier JM, Ibanez P, Mena MA, Abbas N, Cohen-Salmon C, Bohme GA, Laville M, Pratt J, Corti O, Pradier L et al (2003) Parkin gene inactivation alters behaviour and dopamine neurotransmission in the mouse. Hum Mol Genet 12:2277-2291

Jankovic J (2008) Parkinson's disease: clinical features and diagnosis. J Neurol Neurosurg Psychiatry 79:368-376

Kahle PJ, Neumann M, Ozmen L, Muller V, Jacobsen H, Schindzielorz A, Okochi M, Leimer U, van Der Putten H, Probst A et al (2000) Subcellular localization of wild-type and Parkinson's disease-associated mutant alpha-synuclein in human and transgenic mouse brain. J Neurosci 20:6365-6373

Katzenschlager R, Lees AJ (2004) Olfaction and Parkinson's syndromes: its role in differential diagnosis. Curr Opin Neurol $17: 417-423$

Kim RH, Smith PD, Aleyasin H, Hayley S, Mount MP, Pownall S, Wakeham A, You-Ten AJ, Kalia SK, Horne P et al (2005) Hypersensitivity of DJ-1-deficient mice to 1-methyl-4-phenyl-1, 2, 3, 6-tetrahydropyrindine (MPTP) and oxidative stress. Proc Natl Acad Sci USA 102:5215-5220

Kitada T, Pisani A, Porter DR, Yamaguchi H, Tscherter A, Martella G, Bonsi P, Zhang C, Pothos EN, Shen J (2007) Impaired dopamine release and synaptic plasticity in the striatum of PINK1-deficient mice. Proc Natl Acad Sci USA 104:1144111446

Kitada T, Tong Y, Gautier CA, Shen J (2009) Absence of nigral degeneration in aged parkin/DJ-1/PINK1 triple knockout mice. J Neurochem 111:696-702

Koob AO, Ubhi K, Paulsson JF, Kelly J, Rockenstein E, Mante M, Adame A, Masliah E (2010) Lovastatin ameliorates alphasynuclein accumulation and oxidation in transgenic mouse models of alpha-synucleinopathies. Exp Neurol 221:267-274

Kruger R, Kuhn W, Muller T, Woitalla D, Graeber M, Kosel S, Przuntek H, Epplen JT, Schols L, Riess O (1998) Ala30Pro mutation in the gene encoding alpha-synuclein in Parkinson's disease. Nat Genet 18:106-108

Kuo YM, Li Z, Jiao Y, Gaborit N, Pani AK, Orrison BM, Bruneau BG, Giasson BI, Smeyne RJ, Gershon MD et al (2010) Extensive enteric nervous system abnormalities in mice transgenic for artificial chromosomes containing Parkinson disease-associated alpha-synuclein gene mutations precede central nervous system changes. Hum Mol Genet 19:1633-1650

Lang AE, Obeso JA (2004) Challenges in Parkinson's disease: restoration of the nigrostriatal dopamine system is not enough. Lancet Neurol 3:309-316

Langston JW (2006) The Parkinson's complex: parkinsonism is just the tip of the iceberg. Ann Neurol 59:591-596

Langston JW, Ballard P, Tetrud JW, Irwin I (1983) Chronic Parkinsonism in humans due to a product of meperidine-analog synthesis. Science 219:979-980

Larsen K, Hedegaard C, Bertelsen MF, Bendixen C (2009) Threonine 53 in alpha-synuclein is conserved in long-living non-primate animals. Biochem Biophys Res Commun 387:602-605

Lee MK, Stirling W, Xu Y, Xu X, Qui D, Mandir AS, Dawson TM, Copeland NG, Jenkins NA, Price DL (2002) Human alphasynuclein-harboring familial Parkinson's disease-linked Ala$53 \rightarrow$ Thr mutation causes neurodegenerative disease with alpha-synuclein aggregation in transgenic mice. Proc Natl Acad Sci USA 99:8968-8973

Lees AJ (2009) The Parkinson chimera. Neurology 72:S2-S11

Li W, West N, Colla E, Pletnikova O, Troncoso JC, Marsh L, Dawson TM, Jakala P, Hartmann T, Price DL et al (2005) Aggregation promoting $\mathrm{C}$-terminal truncation of alpha-synuclein is a normal cellular process and is enhanced by the familial Parkinson's disease-linked mutations. Proc Natl Acad Sci USA 102: 2162-2167

Li YJ, Deng J, Mayhew GM, Grimsley JW, Huo X, Vance JM (2007) Investigation of the PARK10 gene in Parkinson disease. Ann Hum Genet 71:639-647

Li Y, Liu W, Oo TF, Wang L, Tang Y, Jackson-Lewis V, Zhou C, Geghman K, Bogdanov M, Przedborski S et al (2009) Mutant LRRK2(R1441G) BAC transgenic mice recapitulate cardinal features of Parkinson's disease. Nat Neurosci 12:826-828

Li X, Patel JC, Wang J, Avshalumov MV, Nicholson C, Buxbaum JD, Elder GA, Rice ME, Yue Z (2010) Enhanced striatal dopamine transmission and motor performance with LRRK2 overexpression in mice is eliminated by familial Parkinson's disease mutation G2019S. J Neurosci 30:1788-1797

Lim Y, Kehm VM, Li C, Trojanowski JQ, Lee VM (2010) Forebrain overexpression of alpha-synuclein leads to early postnatal hippocampal neuron loss and synaptic disruption. Exp Neurol 221:86-97

Lin X, Parisiadou L, Gu XL, Wang L, Shim H, Sun L, Xie C, Long CX, Yang WJ, Ding J et al (2009) Leucine-rich repeat kinase 2 regulates the progression of neuropathology induced by Parkinson's-disease-related mutant alpha-synuclein. Neuron 64:807827

Liu MJ, Liu ML, Shen YF, Kim JM, Lee BH, Lee YS, Hong ST (2007) Transgenic mice with neuron-specific overexpression of HtrA2/Omi suggest a neuroprotective role for HtrA2/Omi. Biochem Biophys Res Commun 362:295-300

Liu M, Choi DY, Hunter RL, Pandya JD, Cass WA, Sullivan PG, Kim HC, Gash DM, Bing G (2010a) Trichloroethylene induces dopaminergic neurodegeneration in Fisher 344 rats. J Neurochem 112:773-783

Liu P, Wang X, Gao N, Zhu H, Dai X, Xu Y, Ma C, Huang L, Liu Y, Qin C (2010b) G protein-coupled receptor kinase 5, overexpressed in the alpha-synuclein up-regulation model of Parkinson's disease, regulates bcl-2 expression. Brain Res 1307:134-141 
Lu XH, Fleming SM, Meurers B, Ackerson LC, Mortazavi F, Lo V, Hernandez D, Sulzer D, Jackson GR, Maidment NT et al (2009) Bacterial artificial chromosome transgenic mice expressing a truncated mutant parkin exhibit age-dependent hypokinetic motor deficits, dopaminergic neuron degeneration, and accumulation of proteinase K-resistant alpha-synuclein. J Neurosci 29: 1962-1976

Magen I, Chesselet MF (2010) Genetic mouse models of Parkinson's disease The state of the art. Prog Brain Res 184:53-87

Manning-Bog AB, McCormack AL, Li J, Uversky VN, Fink AL, Di Monte DA (2002) The herbicide paraquat causes up-regulation and aggregation of alpha-synuclein in mice: paraquat and alphasynuclein. J Biol Chem 277:1641-1644

Manning-Bog AB, McCormack AL, Purisai MG, Bolin LM, Di Monte DA (2003) Alpha-synuclein overexpression protects against paraquat-induced neurodegeneration. J Neurosci 23:30953099

Maries E, Dass B, Collier TJ, Kordower JH, Steece-Collier K (2003) The role of alpha-synuclein in Parkinson's disease: insights from animal models. Nat Rev Neurosci 4:727-738

Markesbery WR, Jicha GA, Liu H, Schmitt FA (2009) Lewy body pathology in normal elderly subjects. J Neuropathol Exp Neurol 68:816-822

Martella G, Platania P, Vita D, Sciamanna G, Cuomo D, Tassone A, Tscherter A, Kitada T, Bonsi P, Shen J et al (2009) Enhanced sensitivity to group II mGlu receptor activation at corticostriatal synapses in mice lacking the familial parkinsonism-linked genes PINK1 or Parkin. Exp Neurol 215:388-396

Martin LJ, Pan Y, Price AC, Sterling W, Copeland NG, Jenkins NA, Price DL, Lee MK (2006) Parkinson's disease alpha-synuclein transgenic mice develop neuronal mitochondrial degeneration and cell death. J Neurosci 26:41-50

Martins LM, Morrison A, Klupsch K, Fedele V, Moisoi N, Teismann P, Abuin A, Grau E, Geppert M, Livi GP et al (2004) Neuroprotective role of the Reaper-related serine protease HtrA2/Omi revealed by targeted deletion in mice. Mol Cell Biol 24:9848-9862

Marxreiter F, Nuber S, Kandasamy M, Klucken J, Aigner R, Burgmayer R, Couillard-Despres S, Riess O, Winkler J, Winner B (2009) Changes in adult olfactory bulb neurogenesis in mice expressing the A30P mutant form of alpha-synuclein. Eur $\mathrm{J}$ Neurosci 29:879-890

Mascaro AL, Sacconi L, Pavone FS (2010) Multi-photon nanosurgery in live brain. Front neuroenergetics 2, pii 21

Maskri L, Zhu X, Fritzen S, Kuhn K, Ullmer C, Engels P, Andriske M, Stichel CC, Lubbert H (2004) Influence of different promoters on the expression pattern of mutated human alpha-synuclein in transgenic mice. Neurodegener Dis 1:255-265

Masliah E, Rockenstein E, Veinbergs I, Mallory M, Hashimoto M, Takeda A, Sagara Y, Sisk A, Mucke L (2000) Dopaminergic loss and inclusion body formation in alpha-synuclein mice: implications for neurodegenerative disorders. Science 287:1265-1269

Matsuoka Y, Vila M, Lincoln S, McCormack A, Picciano M, LaFrancois J, Yu X, Dickson D, Langston WJ, McGowan E et al (2001) Lack of nigral pathology in transgenic mice expressing human alpha-synuclein driven by the tyrosine hydroxylase promoter. Neurobiol Dis 8:535-539

McNeill TH, Koek LL (1990) Differential effects of advancing age on neurotransmitter cell loss in the substantia nigra and striatum of C57BL/6 N mice. Brain Res 521:107-117

Melrose HL, Dachsel JC, Behrouz B, Lincoln SJ, Yue M, Hinkle KM, Kent CB, Korvatska E, Taylor JP, Witten L et al (2010) Impaired dopaminergic neurotransmission and microtubule-associated protein tau alterations in human LRRK2 transgenic mice. Neurobiol Dis 40:503-517
Menendez J, Rodriguez-Navarro JA, Solano RM, Casarejos MJ, Rodal I, Guerrero R, Sanchez MP, Avila J, Mena MA, de Yebenes JG (2006) Suppression of Parkin enhances nigrostriatal and motor neuron lesion in mice over-expressing human-mutated tau protein. Hum Mol Genet 15:2045-2058

Meredith GE, Totterdell S, Potashkin JA, Surmeier DJ (2008) Modeling PD pathogenesis in mice: advantages of a chronic MPTP protocol. Parkinsonism Relat Disord 14(Suppl 2):S112S115

Miller RM, Kiser GL, Kaysser-Kranich T, Casaceli C, Colla E, Lee MK, Palaniappan C, Federoff HJ (2007) Wild-type and mutant alpha-synuclein induce a multi-component gene expression profile consistent with shared pathophysiology in different transgenic mouse models of PD. Exp Neurol 204:421-432

Morais VA, Verstreken P, Roethig A, Smet J, Snellinx A, Vanbrabant M, Haddad D, Frezza C, Mandemakers W, Vogt-Weisenhorn D et al (2009) Parkinson's disease mutations in PINK1 result in decreased Complex I activity and deficient synaptic function. EMBO Mol Med 1:99-111

Nass R, Merchant KM, Ryan T (2008) Caenohabditis elegans in Parkinson's disease drug discovery: addressing an unmet medical need. Mol Interv 8:284-293

Neumann M, Kahle PJ, Giasson BI, Ozmen L, Borroni E, Spooren W, Muller V, Odoy S, Fujiwara H, Hasegawa M et al (2002) Misfolded proteinase K-resistant hyperphosphorylated alphasynuclein in aged transgenic mice with locomotor deterioration and in human alpha-synucleinopathies. J Clin Invest 110:14291439

Nieto M, Gil-Bea FJ, Dalfo E, Cuadrado M, Cabodevilla F, Sanchez B, Catena S, Sesma T, Ribe E, Ferrer I et al (2006) Increased sensitivity to MPTP in human alpha-synuclein A30P transgenic mice. Neurobiol Aging 27:848-856

Nishi A, Ishii A, Takahashi A, Shiroishi T, Koide T (2010) QTL analysis of measures of mouse home-cage activity using B6/ MSM consomic strains. Mamm Genome 21:477-485

Norris EH, Uryu K, Leight S, Giasson BI, Trojanowski JQ, Lee VM (2007) Pesticide exposure exacerbates alpha-synucleinopathy in an A53T transgenic mouse model. Am J Pathol 170:658-666

Nuber S, Petrasch-Parwez E, Winner B, Winkler J, von Horsten S, Schmidt T, Boy J, Kuhn M, Nguyen HP, Teismann P et al (2008) Neurodegeneration and motor dysfunction in a conditional model of Parkinson's disease. J Neurosci 28:2471-2484

O'Gorman S, Dagenais NA, Qian M, Marchuk Y (1997) ProtamineCre recombinase transgenes efficiently recombine target sequences in the male germ line of mice, but not in embryonic stem cells. Proc Natl Acad Sci USA 94:14602-14607

Oksman M, Tanila H, Yavich L (2009) Behavioural and neurochemical response of alpha-synuclein A30P transgenic mice to the effects of L-DOPA. Neuropharmacology 56:647-652

Ono K, Ikemoto M, Kawarabayashi T, Ikeda M, Nishinakagawa T, Hosokawa M, Shoji M, Takahashi M, Nakashima M (2009) A chemical chaperone, sodium 4-phenylbutyric acid, attenuates the pathogenic potency in human alpha-synuclein A30P + A53T transgenic mice. Parkinsonism Relat Disord 15:649-654

Paisan-Ruiz C, Jain S, Evans EW, Gilks WP, Simon J, van der Brug M, Lopez de Munain A, Aparicio S, Gil AM, Khan N et al (2004) Cloning of the gene containing mutations that cause PARK8-linked Parkinson's disease. Neuron 44:595-600

Paisan-Ruiz C, Guevara R, Federoff M, Hanagasi H, Sina F, Elahi E, Schneider SA, Schwingenschuh P, Bajaj N, Emre M et al (2010) Early-onset L-dopa-responsive parkinsonism with pyramidal signs due to ATP13A2, PLA2G6, FBXO7 and spatacsin mutations. Mov Disord 25:1791-1800

Palacino JJ, Sagi D, Goldberg MS, Krauss S, Motz C, Wacker M, Klose J, Shen J (2004) Mitochondrial dysfunction and oxidative damage in parkin-deficient mice. J Biol Chem 279:18614-18622 
Pankratz N, Nichols WC, Uniacke SK, Halter C, Murrell J, Rudolph A, Shults CW, Conneally PM, Foroud T (2003) Genome-wide linkage analysis and evidence of gene-by-gene interactions in a sample of 362 multiplex Parkinson disease families. Hum Mol Genet 12:2599-2608

Pankratz N, Wilk JB, Latourelle JC, DeStefano AL, Halter C, Pugh EW, Doheny KF, Gusella JF, Nichols WC, Foroud T et al (2009) Genomewide association study for susceptibility genes contributing to familial Parkinson disease. Hum Genet 124:593-605

Periquet M, Corti O, Jacquier S, Brice A (2005) Proteomic analysis of parkin knockout mice: alterations in energy metabolism, protein handling and synaptic function. J Neurochem 95:1259-1276

Pienaar IS, Daniels WM, Gotz J (2008) Neuroproteomics as a promising tool in Parkinson's disease research. J Neural Transm 115:1413-1430

Plaas M, Karis A, Innos J, Rebane E, Baekelandt V, Vaarmann A, Luuk H, Vasar E, Koks S (2008) Alpha-synuclein A30P pointmutation generates age-dependent nigrostriatal deficiency in mice. J Physiol Pharmacol 59:205-216

Polymeropoulos MH, Lavedan C, Leroy E, Ide SE, Dehejia A, Dutra A, Pike B, Root H, Rubenstein J, Boyer R et al (1997) Mutation in the alpha-synuclein gene identified in families with Parkinson's disease. Science 276:2045-2047

Poon HF, Frasier M, Shreve N, Calabrese V, Wolozin B, Butterfield DA (2005) Mitochondrial associated metabolic proteins are selectively oxidized in A30P alpha-synuclein transgenic mice-a model of familial Parkinson's disease. Neurobiol Dis 18:492498

Prasad K, Tarasewicz E, Ohman Strickland PA, O’Neill M, Mitchell SN, Merchant K, Tep S, Hilton K, Datwani A, Buttini M et al (2011) Biochemical and morphological consequences of human alpha-synuclein expression in a mouse alpha-synuclein null background. Eur J Neurosci 33:642-652

Rajput AH, Voll A, Rajput ML, Robinson CA, Rajput A (2009) Course in Parkinson disease subtypes: A 39-year clinicopathologic study. Neurology 73:206-212

Ramirez A, Heimbach A, Grundemann J, Stiller B, Hampshire D, Cid LP, Goebel I, Mubaidin AF, Wriekat AL, Roeper J et al (2006) Hereditary parkinsonism with dementia is caused by mutations in ATP13A2, encoding a lysosomal type 5 P-type ATPase. Nat Genet 38:1184-1191

Rascol O (2009) "Disease-modification" trials in Parkinson disease: target populations, endpoints and study design. Neurology 72:S51-S58

Ravenstijn PG, Merlini M, Hameetman M, Murray TK, Ward MA, Lewis H, Ball G, Mottart C, de Goyet C, Lemarchand T et al (2008) The exploration of rotenone as a toxin for inducing Parkinson's disease in rats, for application in BBB transport and PK-PD experiments. J Pharmacol Toxicol Methods 57:114-130

Richfield EK, Thiruchelvam MJ, Cory-Slechta DA, Wuertzer C, Gainetdinov RR, Caron MG, Di Monte DA, Federoff HJ (2002) Behavioral and neurochemical effects of wild-type and mutated human alpha-synuclein in transgenic mice. Exp Neurol 175:3548

Ritz BR, Manthripragada AD, Costello S, Lincoln SJ, Farrer MJ, Cockburn M, Bronstein J (2009) Dopamine transporter genetic variants and pesticides in Parkinson's disease. Environ Health Perspect 117:964-969

Robinson PA (2010) Understanding the molecular basis of Parkinson's disease, identification of biomarkers and routes to therapy. Expert Rev Proteomics 7:565-578

Rockenstein E, Mallory M, Hashimoto M, Song D, Shults CW, Lang I, Masliah E (2002) Differential neuropathological alterations in transgenic mice expressing alpha-synuclein from the plateletderived growth factor and Thy-1 promoters. J Neurosci Res 68:568-578
Rodriguez-Navarro JA, Casarejos MJ, Menendez J, Solano RM, Rodal I, Gomez A, Yebenes JG, Mena MA (2007) Mortality, oxidative stress and tau accumulation during ageing in parkin null mice. J Neurochem 103:98-114

Satake W, Nakabayashi Y, Mizuta I, Hirota Y, Ito C, Kubo M, Kawaguchi T, Tsunoda T, Watanabe M, Takeda A et al (2009) Genome-wide association study identifies common variants at four loci as genetic risk factors for Parkinson's disease. Nat Genet 41:1303-1307

Savica R, Rocca WA, Ahlskog JE (2010) When does Parkinson disease start? Arch Neurol 67:798-801

Schapira AH (2006) Etiology of Parkinson's disease. Neurology 66: S10-S23

Schapira AH, Tolosa E (2010) Molecular and clinical prodrome of Parkinson disease: implications for treatment. Nat Rev Neurol 6:309-317

Schapira AH, Agid Y, Barone P, Jenner P, Lemke MR, Poewe W, Rascol O, Reichmann H, Tolosa E (2009) Perspectives on recent advances in the understanding and treatment of Parkinson's disease. Eur J Neurol 16:1090-1099

Schell H, Hasegawa T, Neumann M, Kahle PJ (2009) Nuclear and neuritic distribution of serine-129 phosphorylated alpha-synuclein in transgenic mice. Neuroscience 160:796-804

Sedelis M, Hofele K, Schwarting RK, Huston JP, Belknap JK (2003) Chromosomal loci influencing the susceptibility to the parkinsonian neurotoxin 1-methyl-4-phenyl-1, 2, 3, 6-tetrahydropyridine. J Neurosci 23:8247-8253

Setsuie R, Wang YL, Mochizuki H, Osaka H, Hayakawa H, Ichihara N, Li H, Furuta A, Sano Y, Sun YJ et al (2007) Dopaminergic neuronal loss in transgenic mice expressing the Parkinson's disease-associated UCH-L1 I93 M mutant. Neurochem Int 50: $119-129$

Sharon R, Bar-Joseph I, Mirick GE, Serhan CN, Selkoe DJ (2003) Altered fatty acid composition of dopaminergic neurons expressing alpha-synuclein and human brains with alpha-synucleinopathies. J Biol Chem 278:49874-49881

Sidransky E, Nalls MA, Aasly JO, Aharon-Peretz J, Annesi G, Barbosa ER, Bar-Shira A, Berg D, Bras J, Brice A et al (2009) Multicenter analysis of glucocerebrosidase mutations in Parkinson's disease. N Engl J Med 361:1651-1661

Simon-Sanchez J, Schulte C, Bras JM, Sharma M, Gibbs JR, Berg D, Paisan-Ruiz C, Lichtner P, Scholz SW, Hernandez DG et al (2009) Genome-wide association study reveals genetic risk underlying Parkinson's disease. Nat Genet 41:1308-1312

Singleton AB, Farrer M, Johnson J, Singleton A, Hague S, Kachergus J, Hulihan M, Peuralinna T, Dutra A, Nussbaum R et al (2003) alpha-Synuclein locus triplication causes Parkinson's disease. Science 302:841

Song DD, Shults CW, Sisk A, Rockenstein E, Masliah E (2004) Enhanced substantia nigra mitochondrial pathology in human alpha-synuclein transgenic mice after treatment with MPTP. Exp Neurol 186:158-172

Sotiriou E, Vassilatis DK, Vila M, Stefanis L (2010) Selective noradrenergic vulnerability in alpha-synuclein transgenic mice. Neurobiol Aging 31:2103-2114

Spillantini MG, Crowther RA, Jakes R, Cairns NJ, Lantos PL, Goedert M (1998) Filamentous alpha-synuclein inclusions link multiple system atrophy with Parkinson's disease and dementia with Lewy bodies. Neurosci Lett 251:205-208

Srivastava G, Singh K, Tiwari MN, Singh MP (2010) Proteomics in Parkinson's disease: current trends, translational snags and future possibilities. Expert Rev Proteomics 7:127-139

Steg G (1964) Alpha-rigidity in reserpinized rats. Experientia 20:79-80

Stichel CC, Zhu XR, Bader V, Linnartz B, Schmidt S, Lubbert H (2007) Mono- and double-mutant mouse models of Parkinson's 
disease display severe mitochondrial damage. Hum Mol Genet 16:2377-2393

Su X, Maguire-Zeiss KA, Giuliano R, Prifti L, Venkatesh K, Federoff HJ (2008) Synuclein activates microglia in a model of Parkinson's disease. Neurobiol Aging 29:1690-1701

Su X, Federoff HJ, Maguire-Zeiss KA (2009) Mutant alpha-synuclein overexpression mediates early proinflammatory activity. Neurotox Res 16:238-254

Takahashi N, Miner LL, Sora I, Ujike H, Revay RS, Kostic V, Jackson-Lewis V, Przedborski S, Uhl GR (1997) VMAT2 knockout mice: heterozygotes display reduced amphetamineconditioned reward, enhanced amphetamine locomotion, and enhanced MPTP toxicity. Proc Natl Acad Sci USA 94:99389943

Takazawa C, Fujimoto K, Homma D, Sumi-Ichinose C, Nomura T, Ichinose H, Katoh S (2008) A brain-specific decrease of the tyrosine hydroxylase protein in sepiapterin reductase-null mice as a mouse model for Parkinson's disease. Biochem Biophys Res Commun 367:787-792

Tan EK, Kwok HH, Tan LC, Zhao WT, Prakash KM, Au WL, Pavanni R, Ng YY, Satake W, Zhao Y et al (2010) Analysis of GWAS-linked loci in Parkinson disease reaffirms PARK16 as a susceptibility locus. Neurology 75:508-512

Tanaka A (2010) Parkin-mediated selective mitochondrial autophagy, mitophagy: Parkin purges damaged organelles from the vital mitochondrial network. FEBS Lett 584:1386-1392

Taylor TN, Caudle WM, Shepherd KR, Noorian A, Jackson CR, Iuvone PM, Weinshenker D, Greene JG, Miller GW (2009) Nonmotor symptoms of Parkinson's disease revealed in an animal model with reduced monoamine storage capacity. J Neurosci 29:8103-8113

Thiruchelvam M, Richfield EK, Baggs RB, Tank AW, Cory-Slechta DA (2000) The nigrostriatal dopaminergic system as a preferential target of repeated exposures to combined paraquat and maneb: implications for Parkinson's disease. J Neurosci 20: 9207-9214

Thiruchelvam MJ, Powers JM, Cory-Slechta DA, Richfield EK (2004) Risk factors for dopaminergic neuron loss in human alpha-synuclein transgenic mice. Eur J Neurosci 19:845-854

Tofaris GK, Garcia Reitbock P, Humby T, Lambourne SL, O'Connell M, Ghetti B, Gossage H, Emson PC, Wilkinson LS, Goedert M et al (2006) Pathological changes in dopaminergic nerve cells of the substantia nigra and olfactory bulb in mice transgenic for truncated human alpha-synuclein(1-120): implications for Lewy body disorders. J Neurosci 26:3942-3950

Tolosa E, Gaig C, Santamaria J, Compta Y (2009) Diagnosis and the premotor phase of Parkinson disease. Neurology 72:S12-S20

Tong Y, Pisani A, Martella G, Karouani M, Yamaguchi H, Pothos EN, Shen J (2009) R1441C mutation in LRRK2 impairs dopaminergic neurotransmission in mice. Proc Natl Acad Sci USA 106:14622-14627

Unger EL, Eve DJ, Perez XA, Reichenbach DK, Xu Y, Lee MK, Andrews AM (2006) Locomotor hyperactivity and alterations in dopamine neurotransmission are associated with overexpression of A53T mutant human alpha-synuclein in mice. Neurobiol Dis $21: 431-443$

Ungerstedt U (1968) 6-Hydroxy-dopamine induced degeneration of central monoamine neurons. Eur J Pharmacol 5:107-110

Ungerstedt U, Ljungberg T, Steg G (1974) Behavioral, physiological, and neurochemical changes after 6-hydroxydopamine-induced degeneration of the nigro-striatal dopamine neurons. Adv Neurol 5:421-426

Van Dam D, De Deyn PP (2011) Animal models in the drug discovery pipeline for Alzheimer's disease. Br J Pharmacol. doi: 10.1111/j.1476-5381.2011.01299.x van der Putten $\mathrm{H}$, Wiederhold KH, Probst A, Barbieri S, Mistl C, Danner S, Kauffmann S, Hofele K, Spooren WP, Ruegg MA et al (2000) Neuropathology in mice expressing human alphasynuclein. J Neurosci 20:6021-6029

Vogel G (2003) Genetics. Scientists dream of 1001 complex mice. Science 301:456-457

Von Coelln R, Thomas B, Savitt JM, Lim KL, Sasaki M, Hess EJ, Dawson VL, Dawson TM (2004) Loss of locus coeruleus neurons and reduced startle in parkin null mice. Proc Natl Acad Sci USA 101:10744-10749

Von Coelln R, Thomas B, Andrabi SA, Lim KL, Savitt JM, Saffary R, Stirling W, Bruno K, Hess EJ, Lee MK et al (2006) Inclusion body formation and neurodegeneration are parkin independent in a mouse model of alpha-synucleinopathy. J Neurosci 26:36853696

Wakamatsu M, Ishii A, Iwata S, Sakagami J, Ukai Y, Ono M, Kanbe D, Muramatsu S, Kobayashi K, Iwatsubo T et al (2008a) Selective loss of nigral dopamine neurons induced by overexpression of truncated human alpha-synuclein in mice. Neurobiol Aging 29:574-585

Wakamatsu M, Iwata S, Funakoshi T, Yoshimoto M (2008b) Dopamine receptor agonists reverse behavioral abnormalities of alpha-synuclein transgenic mouse, a new model of Parkinson's disease. J Neurosci Res 86:640-646

Wang L, Fleming SM, Chesselet MF, Tache Y (2008) Abnormal colonic motility in mice overexpressing human wild-type alphasynuclein. Neuroreport 19:873-876

Watson JB, Hatami A, David H, Masliah E, Roberts K, Evans CE, Levine MS (2009) Alterations in corticostriatal synaptic plasticity in mice overexpressing human alpha-synuclein. Neuroscience 159:501-513

Wellstead P, Cloutier M (2011) An energy systems approach to Parkinson's disease. Wiley Interdiscip Rev Syst Biol Med 3:1-6

Winner B, Lie DC, Rockenstein E, Aigner R, Aigner L, Masliah E, Kuhn HG, Winkler J (2004) Human wild-type alpha-synuclein impairs neurogenesis. J Neuropathol Exp Neurol 63:1155-1166

Winner B, Rockenstein E, Lie DC, Aigner R, Mante M, Bogdahn U, Couillard-Despres S, Masliah E, Winkler J (2008) Mutant alphasynuclein exacerbates age-related decrease of neurogenesis. Neurobiol Aging 29:913-925

Winner B, Melrose HL, Zhao C, Hinkle KM, Yue M, Kent C, Braithwaite AT, Ogholikhan S, Aigner R, Winkler J et al (2011) Adult neurogenesis and neurite outgrowth are impaired in LRRK2 G2019S mice. Neurobiol Dis 41:706-716

Witt SN, Flower TR (2006) alpha-Synuclein, oxidative stress and apoptosis from the perspective of a yeast model of Parkinson's disease. FEMS Yeast Res 6:1107-1116

Wood-Kaczmar A, Gandhi S, Yao Z, Abramov AY, Miljan EA, Keen G, Stanyer L, Hargreaves I, Klupsch K, Deas E et al (2008) PINK1 is necessary for long term survival and mitochondrial function in human dopaminergic neurons. PLoS One 3:e2455

Wu N, Joshi PR, Cepeda C, Masliah E, Levine MS (2010) Alphasynuclein overexpression in mice alters synaptic communication in the corticostriatal pathway. J Neurosci Res 88:1764-1776

Yacoubian TA, Cantuti-Castelvetri I, Bouzou B, Asteris G, McLean PJ, Hyman BT, Standaert DG (2008) Transcriptional dysregulation in a transgenic model of Parkinson disease. Neurobiol Dis 29:515-528

Yasuda T, Nihira T, Ren YR, Cao XQ, Wada K, Setsuie R, Kabuta T, Hattori N, Mizuno Y, Mochizuki H (2009) Effects of UCH-L1 on alpha-synuclein over-expression mouse model of Parkinson's disease. J Neurochem 108:932-944

Yavich L, Oksman M, Tanila H, Kerokoski P, Hiltunen M, van Groen T, Puolivali J, Mannisto PT, Garcia-Horsman A, MacDonald E et al (2005) Locomotor activity and evoked dopamine release are 
reduced in mice overexpressing A30P-mutated human alphasynuclein. Neurobiol Dis 20:303-313

Yavich L, Jakala P, Tanila H (2006) Abnormal compartmentalization of norepinephrine in mouse dentate gyrus in alpha-synuclein knockout and A30P transgenic mice. J Neurochem 99:724-732

Yoshino H, Tomiyama H, Tachibana N, Ogaki K, Li Y, Funayama M, Hashimoto T, Takashima S, Hattori N (2010) Phenotypic spectrum of patients with PLA2G6 mutation and PARK14linked parkinsonism. Neurology 75:1356-1361

Yu WH, Matsuoka Y, Sziraki I, Hashim A, Lafrancois J, Sershen H, Duff KE (2008) Increased dopaminergic neuron sensitivity to 1-methyl-4-phenyl-1, 2, 3, 6-tetrahydropyridine (MPTP) in transgenic mice expressing mutant A53T alpha-synuclein. Neurochem Res 33:902-911
Zhou W, Milder JB, Freed CR (2008) Transgenic mice overexpressing tyrosine-to-cysteine mutant human alpha-synuclein: a progressive neurodegenerative model of diffuse Lewy body disease. J Biol Chem 283:9863-9870

Zhu XR, Maskri L, Herold C, Bader V, Stichel CC, Gunturkun O, Lubbert H (2007) Non-motor behavioural impairments in parkindeficient mice. Eur J Neurosci 26:1902-1911

Zimprich A, Biskup S, Leitner P, Lichtner P, Farrer M, Lincoln S, Kachergus J, Hulihan M, Uitti RJ, Calne DB et al (2004) Mutations in LRRK2 cause autosomal-dominant parkinsonism with pleomorphic pathology. Neuron 44:601-607 